\title{
Örgütsel Başarısızlık: İşletme Fonksiyonları Açısından Bir Değerlendirme
}

\author{
Organizational Failure: An Evaluation in Terms of Business Functions
}

\author{
Rabia Kübra TÜNEL ${ }^{1}$ \\ Yasemin HANCIOĞLU² \\ Derya ÖZTÜRK ${ }^{3}$
}

\author{
Derleme Makale / Review Article \\ Geliș Tarihi / Received: 01.10.2021 \\ Kabul Tarihi / Accepted: 10.11.2021 \\ Doi: 10.48146/odusobiad.1001564
}

Atıf / Citation: Tünel, R. K., Hancıoğlu, Y ve Öztürk, D., (2021). "Örgütsel Başarısızlık: İșletme Fonksiyonları Açısından Bir Değerlendirme”, ODÜSOBİAD, 11(3), 1035-1052, Doi: 10.48146/ odusobiad.1001564

\section{Öz}

Küreselleşmenin artması, iletişim ve bilişim teknolojilerindeki gelişmeler, inovasyonun öneminin artması günümüzdeki rekabet anlayıșını değiştirmektedir. İşletmeler değişen bu rekabet anlayışıyla birlikte yeni arayışlara doğru yönelmektedir. İşletmelerin geleneksel amaçlarından biri olan kar elde etmektir. Bununla birlikte, değișen rekabet anlayıșına uyum sağlayarak topluma hizmet etmesi ve yaşamını sürdürmesi gerekmektedir. Birden fazla amaca aynı anda etkili ve verimli bir șekilde ulașmaya çalışan işletmelerin, hem örgütsel hem de çevresel faktörlerden dolayı başarısızlıkla karşılaşma ihtimalleri vardır. Bu başarısızlığı tespit edebilmek, yönetebilmek ve ortadan kaldırabilmek üst düzey yöneticiler ve departman (fonksiyon) yöneticilerinin sorumluluğundadır. Her yönetici başarısızlıkla karşı karşıya kalma riskinin bilincinde olmalı ve başarısızlığı ortadan kaldırmada etkin rol oynamalıdır. Çalışmada örgütsel başarısızlığa neden olabilecek faktörler işletme fonksiyonları açısından ayrı ayrı ele alınmaktadır. Tüm fonksiyonlar açısından bir değerlendirmenin yapılmasının nedeni ise, her bir fonksiyonun işletmenin amaçlarına ulaşmasında katkıda bulunmasıdır. Örgütsel bașarısızlık ancak bütüncül bir bakıș açısıyla tam olarak anlașılabilecektir. Çalıșmada ayrıca bütüncül bir değerlendirme yapılarak başarısızlık faktörlerinin nasıl başarı faktörlerine dönüștürülebileceği, fonksiyon yöneticilerinin hangi sorumlulukları alması gerektiği tartışılmaktadır. Yapılan teorik değerlendirme sonucunda, işletme fonksiyonlarından kaynaklanan bazı başarısızlık faktörlerinin birbirleriyle ilişkili olduğu ve işletmenin etkililiğini olumsuz yönde etkilediği söylenebilir. Bu olumsuz etkiyi azaltmak ya da ortadan kaldırmak disiplinler arası holistik bakış açısı ile mümkün olabilecektir.

Anahtar Kelimeler: Örgütsel başarısızlık, Yönetim, Pazarlama, Üretim, Muhasebe ve Finans Fonksiyonları

\begin{abstract}
Increasing globalization, developments in communication and information technologies, increasing the importance of innovation change today's understanding of competition. Businesses are heading towards new searches with this changing understanding of competition. One of the traditional goals of businesses is to make profit. However, it needs to serve the society and survive by adapting to the changing understanding of competition. Businesses trying to achieve multiple goals effectively and efficiently at the same time are likely to encounter failure due to both organizational and environmental factors. It is the responsibility of senior managers and department (function) managers to detect, manage and eliminate this failure. Every manager should be aware of the risk of facing failure and play an active role in eliminating failure. In the study, factors that can cause organizational failure are discussed separately in terms of business functions. The reason for making an evaluation in terms of all functions is that each function contributes to the achievement of the goals of the business. Organizational failure can only be fully understood from a holistic perspective. The study also discusses how failure factors can be transformed into success factors by making a holistic evaluation, and what responsibilities function managers should take. As a result of the theoretical evaluation, it can be said that some failure factors arising from business functions are related to each other and negatively affect the efficiency of the business. It will be possible to reduce or eliminate this negative effect with an interdisciplinary holistic perspective.
\end{abstract}

Keywords: Organizational failure, Administration, Marketing, Production, Accounting and Finance Functions

1Sorumlu Yazar, Arş. Gör. Ankara Üniversitesi, Siyasal Bilgiler Fakültesi, İșletme Bölümü, ANKARA/TÜRKİYE, e-posta: rktufaner@ankara.edu.tr, ORCID ID: 0000-0003-0090-3114.

${ }^{2}$ Doç. Dr. Ordu Üniversitesi, Ünye Meslek Yüksekokulu, Muhasebe ve Vergi Bölümü, ORDU/TÜRKIYYE, e-posta: yaseminhancioglu@odu.edu.tr, ORCID ID: 0000-0002-6337-1314.

${ }^{3}$ Doç. Dr. Ordu Üniversitesi, Ünye İktisadi ve İdari Bilimler Fakültesi, İşletme Bölümü, ORDU/TÜRKIYYE, e-posta: deryaozturk@odu.edu.tr, ORCID ID: 0000-0001-5287-6600. 


\section{Giriş}

Rekabet, bütün olarak değerlendirildiğinde ekonomiye fayda sağlamaktadır. Bunu da girișimi teșvik ederek ve kaynakların etkili ve verimli şekilde kullanılmasını sağlayarak gerçekleştirmektedir (De Bono, 2000, s. 85). Günümüzde rekabet edebilirlik daha zorlu hale gelmiştir. İşletmelerin faaliyette bulundukları çevre faktörlerinin çok hızlı değiştiği görülmektedir. İşletmelerin bu değişime ayak uydurabilmesi ve yaşamını sürdürebilmesi, işletmeleri yeni arayışlara doğru yönlendirmektedir.

İșletmelerin yeni arayışlarına yön veren önemli kavramlardan biri ise sürdürülebilirlik olarak karşımıza çıkmaktadır. Sürdürülebilirlik, üretkenlik ve çeşitliliğin devam etmesi sağlanırken, sürekli olabilme özelliğini korumaktır (Hancıoğlu ve Türkoğlu, 2017, s. 238). Sürdürülebilirlik kavramı işletme fonksiyonlarıyla yakından ilişkilidir. İşletme fonksiyonlarında karşı karşıya kalınan bir aksama, yanlış stratejinin benimsenmesi, yanlış kararların uygulamaya aktarılması, olayların statik bir biçimde ele alınması gibi durumlar örgütsel başarısızlık kavramını ortaya çıkarabilir. Örgütsel başarısızlığa neden olabilecek durumlar bazen yöneticiler tarafından önemsiz, geçici, belli bir fonksiyonu ya da belli bir paydaşı etkileyen bir durum şeklinde değerlendirilerek görmezden gelinebilir. Örgütsel başarısızlığa neden olabilecek her bir faktör işletme üzerindeki etki boyutu ne olursa olsun yöneticiler tarafından incelenmeli, ortadan kaldırılmalı ya da azaltılması adına düzenleyici önlemler alınmalıdır. Aksi takdirde işletmenin sürdürülebilirliği tehlikeye girecek, örgütsel başarısızlığın kümülatif etkisi belki de işletmenin yaşamının sonlanmasına neden olabilecektir. Çalışmada bu doğrultuda, örgütsel başarısızlığa neden olabilecek faktörler fonksiyon temeline göre ele alınmıştır.

İşletmelerin kurulma esnasında aklına gelebilecek en son düşünce örgütsel başarısızlığa uğrayabilecek olmalarıdır. Fakat işletmelerin dönem içerisinde çok çeşitli sebeplerle faaliyetlerini devam ettiremez hale geldikleri ve böylece başarısız olabildikleri de bilinen bir gerçektir. Hatta başarısız olan işletmelerin sayısının başarılı olan işletmelerden çok daha fazla olduğu da bilinmektedir. Yine de yapılan çalışmalarda, örgütsel başarısızlığın incelenmesi her zaman örgütsel başarıya göre ikincil olarak değerlendirilmektedir. Yani başarısızlık genellikle daha az önemli ya da örgütsel başarı üzerine araştırmayı tamamlayıcı olarak görülmektedir (Mellahi ve Wilkinson, 2010, s. 531).

İşletmelerin başarısızlıklarının etkilemiş oldukları alanların çok geniş olması sebebiyle bu konuya olan ilgi de artmıştır. Bu bağlamda işletmelerin yaşam döngüleri boyunca başarısızlığa uğramalarına neden olan faktörlerin ortaya çıkarılması, başarısızlık sürecinin yönetilmesi ve de işletmelerin faaliyetlerinin sürdürülemez hale gelmeden önce tahmin etmeyi mümkün hale getiren erken ikaz sistemlerinin tanımlanmasıyla ilgili olarak çalışmalar yapılmıştır. İşletmeler geleneksel yönetim anlayışlarından vazgeçerek, bilgiye dayanan iş yapma yöntemlerini uygulamaya geçirmeleri yani aynı zamanda da işletmenin tüm birimleriyle entegre çalışmaları gereklidir. Bilgiye dayanan iş yapma yöntemlerini kullanmayan yani entegre olamayan işletmeler örgütsel başarısızlığa mahkumdurlar.

\section{Örgütsel Başarısızlık Kavramı}

Başarısızlık teriminin, akademik literatürde farklı tanımlarının keşfedilmesiyle birlikte birçok anlama sahip olduğu söylenebilir. Bilim insanları işletmelerdeki başarısızlıklara atıfta bulunmak için duraklama, örgütsel ölüm, piyasadan çıkma, iflas, kısıntı (azaltma) ve aksaklıklar gibi terimleri kullanmaktadırlar.

Başarısızlık, hem biyolojik sistemlerin hem de sosyal ve ekonomik organizasyonların en temel özelliğidir (Ormerod 2005'ten aktaran Mellahi ve Wilkinson, 2010). Başarısızlığın bağlamı dış etkiler içerse de, başarısızlık için kontrol odağı organizasyonun içindedir ve başarısızlık yöneticilerin "eylemleri veya ihmalkar eylemsizliği" sonucunda ortaya çıkmaktadır (Gillespie ve Dietz, 2009:129).

Örgütsel başarısızlık, "kaynak sıkıntısı, istikrarsız hedef tercihleri ve stratejik seçeneklerin yetersiz olduğu bir durum" şeklinde tanımlanmaktadır. Örgütsel başarısızlık büyük ölçüde, işletme fonksiyonlarındaki olumsuzlukların bir işlevidir (McMillan ve Overall, 2017, s. 272-273). Örgütsel başarısızlık "bir organizasyonun kendi mikro nișine (microniche) adaptasyonundaki bir bozulma ve bununla bağlantılı olarak organizasyon içindeki kaynakların azalması" şeklinde tanımlanabilir (Cameron ve diğerleri, 1988, s. 9'dan aktaran Mellahi ve Wilkinson, 2004, s. 22). Başka bir tanıma göre ise, örgütsel başarısızlık; (1) operasyonların istemsiz bir şekilde durdurulması, (2) işletmenin iflas etmesi veya (3) sahiplikte istem dışı bir değişikliktir (Habersang ve diğerleri, 2019). 
Bir kuruluşun rekabet etme yeteneği, uygulanabilirliği tehdit eden kritik bir eşiğin altında bozulduysa örgütsel başarısızlık kavramından bahsedilebilir. Örgütsel başarısızlığın belirtileri arasında pazar payının kaybedilmesi, sürekli düşük veya negatif karlılık, kritik kaynaklarda (finansal, beșeri ve teknolojik) daralma ve/veya meșruiyet kaybı sayllabilir (Mellahi ve Wilkinson, 2010).

Başarısızlık, kuruluşun meşruiyetini tehdit eden ve kuruluşun bir veya daha fazla paydaşının refahına zarar verme potansiyeline sahip olan organizasyonel temsilcilerin eyleminden (veya eylemsizliğinden) kaynaklanan tek bir büyük olay veya kümülatif olaylar dizisi olarak tanımlanmaktadır. Bu durumlar şu şekilde belirtilebilir (Gillespie ve Dietz, 2009, s. 128-129):

- $\quad$ Birincisi örgütsel başarısızlı̆ı̆n, örgütsel düzeyde kendini göstermesi için başarısızlığın örgütün meşruiyetini tehdit edebilecek kadar büyük olması gerekmektedir. Meşruiyet krizi, başarısızlığın iki açıdan sorgulanmasından kaynaklanabilir: (1) kuruluşun temel misyonunu veya temel sorumluluklarından birini yerine getirme kapasitesi (örneğin, P\&O Ferries için güvenli ulaşım, New York Times için doğru gazetecilik), (2) kuruluşun yaygın olarak kabul edilen etik standartları benimseme durumu (örneğin, ölüme neden olabilecek, istismarcı veya dürüst olmayan iş uygulamalarından kaçınma).

- İ́kincisi, bașarısızlıktan kaynaklanan algılanan potansiyel veya gerçek zarar, çalıșanların kendileri tarafından değil, müşteriler, hissedarlar veya daha geniş bir etki düzeyiyle toplum gibi paydaşlar tarafından karşılanabilir.

- $\quad$ Üçüncüsü, başarısızlık, organizasyonda yetkilendirilen, bilgilendirilen ve görevi yerine getirme adına olanaklar tanınan çalışanların eylemlerinin veya ihmalkar bir tavırla eylemsizliklerinin bir sonucu olarak ortaya çıktığının düşünülmesidir.

Başarısızlık fikrinde, hem zamanla oluşan, kümülatif bir süreci hem de aralıklarla oluşan durum temelli bir oluşumu içeren çerçeveyi anlamak önemlidir. Organizasyonun farklı seviyelerde hazırlıklı olması adına çok sayıda değişken tanımlanır. Değişkenlerin belirlenmesi aşamasında örgütsel çöküş için bir katalizör olarak hareket etme potansiyeline sahip dış olaylar gözden geçirilir. Örgütsel bağlamda insan eylemlerinin doğasında bulunan kusurlar ve başarısızlıklar da, giderek daha ciddi durumlara ve başarısızlık süreçlerine dönüşme riski taşır. İç ve dış faktörler ile çalışan ve yönetici davranışlarından kaynaklanan durumlar birbirinin üzerine birikerek basit, karmaşık ve felakete yol açan başarısızlıklarda kendini göstermektedir (McMillan ve Overall, 2017, s. 275-276).

Organizasyon düzeyinde hatalar sonucunda ortaya çıkabilecek başarısızlıklar, finansal skandalları (örn, Enron, Worldcom, Parmalat), aldatma (örn, New York Times tarafından ortaya konulan intihal ve uydurma raporları), yetersizlik (örn, ABD Federal Acil Durum Yönetim Ajansı'nın Katrina kasırgasına tepkisi), ölümcül, önlenebilir kazalar (örn, Union Carbide'ın Bhopal'daki kimyasal sızıntısı, BP'nin Texas rafinerisindeki yangını), savunmasız kişilerin kullanılması (örn, çalışma şartları kötü işyerlerinde çocuk işçilerin çalıştırılması), büyük zorunlu iş kayıpları (örn, 1990'larda IBM), organizasyonun finansal yapısında büyük çöküşler ve iflaslar (örn, AIG, Freddie Mac ve Fannie Mae, Northern Rock) șeklinde belirtilebilir (Gillespie ve Dietz, 2009, s. 127).

McMillan ve Overall (2017, s. 275-276), başarısızlığı farklı stratejik örgütsel kapasitelerle ilgili üç karar verme seviyesinde zamanla olușan ve kümülatif bir yanlış hizalama süreci olarak kavramsallaştırmaktadır. Bu durum, organizasyonel hedeflerle ilgili olarak karar alma ve uygulamaya aktarma sürecinde yanlış hizalamaların sayısının artması ve sonuçta felaket getiren başarısızlıkla karşılaşma anlamına gelmektedir. Bir organizasyonda yanlış hizalamalar hem dikey hem de yatay olarak oluşturulabilir.

McMillan ve Overall (2017, s. 272-273) tarafından organizasyonlarda başarısızlığa neden olabilecek üç konu bağlamında stratejik kapasiteyi ele alan yönetim perspektifi sağlayan bir model oluşturulmuştur: Örgütsel öğrenme, örgütsel planlama, örgütsel çeviklik, her biri sırasıyla, basit, karmaşık ve felakete yol açan başarısızlıklara neden olabilmektedir. Modelde, belirli olaylar önemlidir, ancak örgütsel başarısızlı̆̆ın zamana dayalı bir süreç olduğu fikriyle tanımlanabilen içsel süreçlerde önemlidir. İlk seviyede, genellikle taktiksel ve operasyonel faaliyetlerde örgütsel öğrenmenin yeterli düzeyde olmaması (veya örgütsel öğrenmeden sapma), genellikle çalışan veya müşteri açısından basit başarısızlıkları beraberinde getirmektedir. Bu durumun telafi edilmesi ve 
örgütsel öğrenmenin gerçekleşmesi adına bazı önlemler alınmaktadır. İkinci seviyede, gelecekteki olaylar ve olay döngüleri hakkında öngörü eksikliği veya minimum planlama, karmaşık başarısızlıklara yol açmaktadır. Karmaşık başarısızlıklar, işletmenin hayatını sürdürmesi ve performansını arttırarak devam edebilmesi adına yüksek risk içeren zorluklar yaratır. Karmaşık başarısızlıklara örnek olarak, müşteri ihtiyaçlarıyla uyuşmayan ürün lansmanları, hastanede bir hastaya yanlış teşhis konulması ve bir yazılım programında tekrarlayan hatalar sayılabilir. Örgütsel öğrenmenin yetersiz olması ve planlamada öngörü eksikliğinin kümülatif etkisi, üçüncü seviyeye, yani felakete yol açan başarısızlıklara neden olabilir. Bu başarısızlık bir organizasyonun her düzeyinde meydana gelen ve büyük yapısal kurumsal dönüşümler olmadan düzeltilemeyen toplam başarısızlık şeklinde ifade edilebilir.

Mellahi ve Wilkinson (2004, s. 32-33) tarafından oluşturulan modelde örgütsel başarısızlığın belirleyicileri dört başlıkta ele alınmıştır: Çevresel faktörler, ekolojik faktörler, organizasyonel faktörler, psikolojik faktörler. Bununla birlikte, örgütsel başarısızlığı daha iyi anlamak için dış etkenlerin ve örgütsel faktörlerin başarısızlığa neden olacak şekilde nasıl etkileşime girdiğinin anlaşılması gerekmektedir. Dış ve iç çevrenin çeşitli yönlerinin etkisi ve bu çevreler arasındaki ilişkiyi tasvir eden kavramsal çerçeve şekilde görülmektedir (Görsel 1). Bütünleștirici çerçevenin temel bir aksiyomu, her bir perspektifin altında incelenen farklı teorik varsayımların ve bağlantıların uzlaştırılması değil, aynı zamanda, birlikte örgütsel başarısızlığın tek bir perspektiften daha kapsamlı bir şekilde anlaşılmasını sağlamasıdır. Kesikli çizgiler, çevresel ve ekolojik faktörlerin, örgütsel faktörler üzerinde bağımsız bir etkisi olabileceğini belirtmektedir. Bu doğrudan etkilerin aşırı durumlarda geçerli olacağı ileri sürülmektedir (büyük çevresel felaketler, ekonomik krizler, Enron ve Worldcom vakalarında olduğu gibi yönetimin yanlıș davranıșları). İç çevre ve dıș çevre arasındaki etkileșimler R1 ve R2 ile temsil edilmektedir. İșletme düzeyinde, model genellikle yönetim eylemlerinin tek başına başarısızlığa yol açmadığını göstermektedir. Yönetim eylemlerinin öngörülebilirliğini arttırmak için, endüstri dinamikleri ve ișletmenin faaliyet gösterdiği çevre daha geniş bağlamda ele alınmalıdır. Model, farklı iş çevrelerindeki işletmelerin aynı iç faktörlerde farklılıklar göstereceğini ileri sürmektedir. Önerilen modelde, yoğunluk, büyüklük, yaș, endüstri yaşam dengesi, organizasyonel faktörlerin örgütsel başarısızlık üzerindeki etkilerine aracılık edebilir (R1).

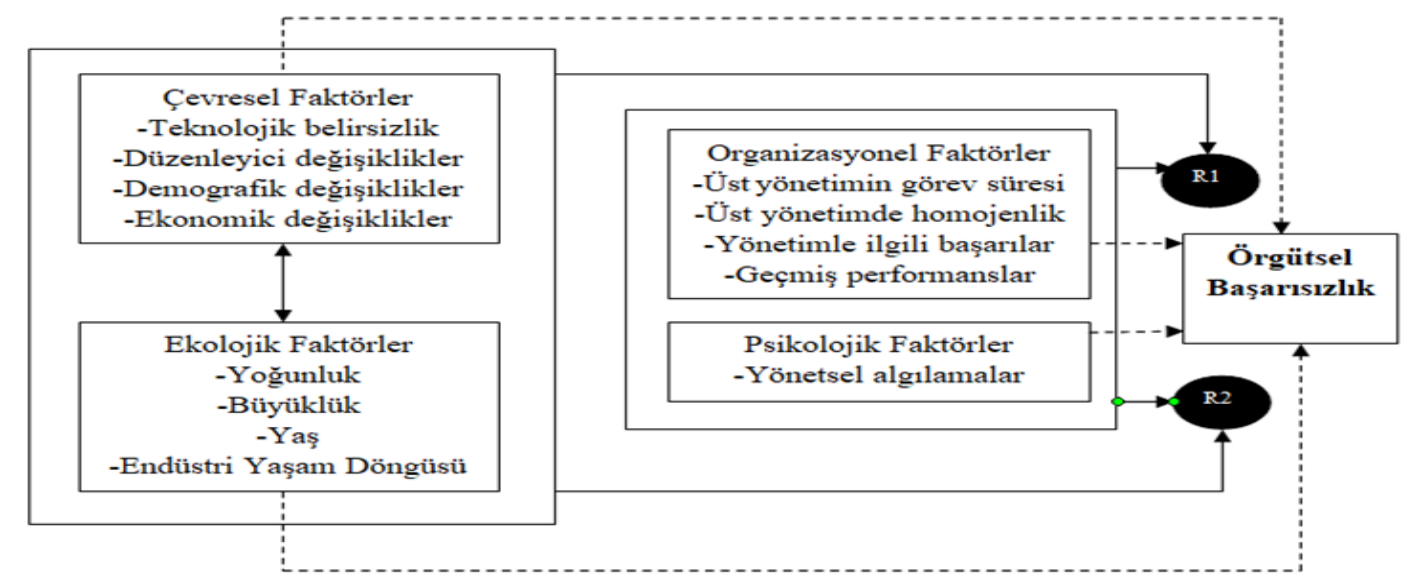

Görsel 1. Örgütsel başarısızlı̆̆ın belirleyicilerinin bütünleştirici bir çerçevesi (Mellahi ve Wilkinson, 2004)

Miner ve diğerlerinin (1996) çalışmalarında 6 örgütsel başarısızlık faktörü tanımlanarak, iki kategoriye ayrılmıştır: Doğrudan ve yorumlayıcı etkiler. Her işletmede ortaya çıkabilecek içsel veya fiili örgütsel başarısızlığın, popülasyon düzeyinde bir öğrenme çerçevesi uygulayarak popülasyon düzeyindeki dönüşümü etkileyebileceği araştırılmıştır. Popülasyon düzeyinde öğrenme, ortak deneyimlerden kaynaklanan bir organizasyon popülasyonunda rutinler ve yapıdaki sistematik değişim şeklinde tanımlanmaktadır.

Başarısızlı̆̆ın doğrudan etkileri (Miner ve diğreleri. 1996: 239-241), 
- Seçilen organizasyonların ve rutinlerin kaldırılması (Removal of selected organizational and routines): Ekonomik ve örgütsel teoriler uzun zamandır organizasyonların ve rutinlerin kaldırılmasıyla değișebileceğini ileri sürüyorlardı. Geleneksel ekonomik teori, başarısızlığı, başarısızlıklardan sonra popülasyonda farklı rutinlerin birleşimini sağlayan verimsiz örgütleri ortadan kaldırmanın bir yolu olarak görmektedir.

- $\quad$ Kaynakların serbest bırakılması (Release of resources): İlgili etki, bir işletmenin fiili veya içsel başarısızlığından dolayı kaynakların o işletmeden diğer bir işletmeye tahsis edilmesiyle ortaya çıkmaktadır. Bir işletmedeki başarısızlık, bir diğerinin gelişimi için kısmi bir canlandırıcı görevi görmektedir. Belirli işletmelerin başarısızlıkları, daha sonra yeni işletmelere tahsis edilebilecek yönetsel ve teknik yetenekleri ortaya çıkarmaktadır.

Herhangi bir sektörde, bir işletmenin başarısızlığı, yeni alanlarda çaba göstermeye yardımcı olan zaman ve dikkati de serbest birakabilir (Barlett, 1983'ten aktaran Miner ve diğerleri, 1996).

- $\quad$ Telafi edici uygulama (Compensating action): Bir endüstride daha fazla başarısızlı̆̆ın önüne geçme çabaları, işletmelerin içsel veya fiili başarısızlıklarının üçüncü önemli maddi sonucunu temsil eder. Hükümet faaliyetleri, bu müdahalelerin önemli bir kaynağını temsil etmektedir.

- Uyarı etkisi (Allerting effect): Örgütsel bașarısızlı̆̆ın diğer bir potansiyel etkisi, bir endüstrideki diğer işletmeler için uyarı etkisidir. Bölgesel ekonomilerin ve bazı endüstrilerin açıklamaları, büyük işletmelerin başarısızlıklarının veya dramatik gerilemelerinin, diğer işletmeleri kendi endüstrileri veya en azından işlerini uygulama veya yürütmede temel sorunlar olabileceği sonucuna varmaya teşvik edebilmektedir.

- $\quad$ Çıkarımsal öğrenme (Inferential learning): Diğer ortamlardaki başarısızlık, bir şeylerin yanlış olduğuna dair bir sinyalden fazlası olarak hizmet edebilir ve belirli temel işlerin potansiyel değeri veya bunları gerçekleştirme yöntemleri hakkında çıkarımsal öğrenmeye izin verebilmektedir.

- $\quad$ İkinci el meşruiyet (Second-hand legitimacy): Örneğin, Amerika Birleşik Devletleri radyo yayıncılığı topluluğundaki endüstri evriminin birkaç aşaması.

Bireyler ve yöneticiler başarısızlık tehdidi gibi olumsuz koşullarla karşılaştıklarında, davranışları iki boyuta göre değişebilir: görevi yerine getirme veya ihmal. Görevi yerine getirme yani eylem, yöneticilerin tehdidin bilinçli veya başka bir şekilde farkına varması ve bununla aktif olarak başa çlkma derecesini ifade eder. İhmal, yöneticilerin bilişsel olarak dikkatlerini mevcut durumdan ne ölçüde uzaklaştırabilecekleri ve aktif olarak statükoyu sürdürmeye çalışabilecekleri anlamına gelmektedir (Mellahi ve Wilkinson, 2010, s. 535).

Örgütsel başarısızlığa kısmen katkıda bulunabilecek beş psikodinamik faktör listelenmiştir: inkar, rasyonelleştirme, idealleştirme, hayal etme ve simgeleştirme. Bu faktörler bireysel ve organizasyonel öğrenmenin önündeki engeller açısından ele alınmaktadır, bununla birlikte aynı zamanda örgütsel başarısızlıkla ilgilidir (Brown ve Starkey, 2000).

İnan, Besler ve Tonus (2006) örgütsel başarısızlık nedenleri ve yöneticilerin başarısızlığı başarıya dönüștürme yollarını araştırmışlardır. Araștırma sonuçları, araştırmaya katılan yöneticilerin örgütsel başarısızlık nedeni olarak gördüğü ilk beş faktörün; nitelikli işgücü eksikliği, planlama yetersizliği, yönetim yetersizliği, ürün ve teknoloji geliştirme yetersizliği, değişime uyum yetersizliği olduğunu ortaya çıkarmıştır. Başarısızlığın üstesinden gelmede kullandıkları ilk beş yöntem arasında etkisiz yöneticilerin tolere edilmesi, yönetici geliştirmeye öncelik verilmesi, her düzeyde etkili planların yapılması, değişime hızla uyum sağlanması, çalışanların motive edilmesi yer almaktadır.

Thornhill ve Amit (2003) başarısızlı̆̆ın nedenlerinin ișletme yașının bir fonksiyonu olarak değiştiğine dair genel önermeyi, 339 Kanadalı işletmenin iflas örneklerinden alınan verilerle değerlendirmişlerdir. İşletme başarısızlığının altında yatan faktörleri ve yeni işletmelerin başarısızlık mekanizmalarını eski işletmelerle karşılaştırmışlardır. Değerlendirme sonuçları genç işletmelerin yönetim bilgisi ve finansal yönetim yeteneklerindeki yetersizlikler nedeniyle başarısız olduklarını doğrulamaktadır. Öte yandan eski işletmelerin çevresel değişime uyum sağlayamaması nedeniyle başarısız olma olasılığı yüksektir. 
Örgütsel başarısızlığa olan ilgi artışı dikkat çekici olsa da, örgütsel başarısızlıkla ilgili araştırmaların çoğu farklı disiplinler arasında büyük ölçüde bölünmüş durumdadır ve durum hala da böyledir. Farklı disiplinlerden bilim insanları farklı araştırma sorularını ele alırlar, araștırmaları farklı teorik temeller üzerine inşa ederler, farklı metodolojik yaklaşımlar kullanırlar ve farklı sonuçlara ulaşırlar. Sonuç, örgütsel başarısızlığın nedenleri, örgütsel başarısızlığım yönetimi, nassl önlenebileceği veya düzeltilebileceği hakkında farklı bakış açılarının olduğu ve farklı disiplinlerdeki teorisyenlerin söylemlerinden oluşan bir "Babil Kulesi" etkisidir. İşletme ve yönetim araştırmalarında, örgütsel başarısızlık çalışmaları örgütsel başarıyı konu alan çalışmalara göre her zaman ikincil olarak kabul edilmiștir (Mellahi ve Wilkinson, 2010).

\section{Örgütsel Başarısızlı̆̆ın İşletme Fonksiyonları Açısından Değerlendirilmesi}

\section{Yönetim Fonksiyonu}

Yönetim ve organizasyon alanında araștırma yapan bilim insanlarını şaşırtan temel soru şudur: Organizasyonlar neden ve nasıl başarısız olur?. Bu sorudan hareketle aşağıda yönetim ve organizasyon alanında örgütsel başarısızlığa neden olabilecek faktörler incelenmiştir.

Yönetsel başarının çalışanların doğru şekilde yönetilmesine bağlı olduğu bir gerçektir. Çalışanların örgüt hakkındaki algıları, birbirleriyle ve yöneticileri ile ilişkileri, olumlu/olumsuz düşünceleri, yöneticileri pek çok örgütsel davranış konusuyla karşı karşıya getirmektedir. Örgütsel sessizlik, örgütsel sinizm, örgütsel stres, örgütsel tükenmişlik, örgütsel dedikodu, örgütsel intikam, örgütsel mağduriyet, örgütsel sahtekarlık, örgütsel yabancılaşma gibi çalışanların performansını, örgüte bağlılı̆̆ını, iș tatminini ve örgütsel anlamda verimliliği azaltabilecek konular yöneticiler tarafından tespit edilmez ve gerekli önlemler alınmaz ise örgütsel başarısızlığa neden olabilecektir. Örgütsel sessizlik, çalışanların örgüt ile ilgili problemler ve katkı sağlanabilir alanlar ile ilgili bilgi, görüş ve düşüncelerini; bilişsel, duygusal ve davranışsal sebepler ile kolektif olarak örgüt ile paylaşmaması şeklinde tanımlanmaktadır (Bayın Donar, 2019, s. 288). Örgütsel sinizm, bireylerin çalışmakta olduğu örgüte yönelik, kuşku ve hayal kırıklığına dayanan güçlü olumsuz duygularla geliştirdiği negatif tutumdur (Yeşilaydın, 2019).

Örgütsel yaşamda strese yol açabilecek faktörler işin yapılış şekli ile ilgili olabileceği gibi, örgüt yapısından, fiziksel çevre şartlarından ya da bireylerin kendi özelliklerinden kaynaklanabilir. Örgütün amaç ve yöntemlerinin belirgin olmaması, bölümler arası çekişmeler, sıkı gözetim, kararlara katılamama, sistemdeki karmaşıklıklar, örgütteki bireylere beslenen duyarlılık düzeyi, çalışma ortamının sıcaklık, nem oranı, ışıklandırma, gürültü durumu, çok fazla veya çok az iş, zaman baskısı, vardiyalı çalışma düzeni, işte tehlike unsurunun varlığı, rol belirsizliği ve rol çatışması, iş güvensizliği, çalışanın isteklerinin engellenmesi, ilerleme olanağının olmaması, yetki ve sorumluluk dağılımındaki güçlükler, davranışların kısıtlanması, amaçlarla çatışan politikalar işletme içinde önemli stresler oluştururlar. Yanlış yönetilen bir stresin hem bireysel hem de örgütsel maliyeti oldukça fazladır (Özkalp ve Kırel, 2005, s. 431-442). Bu durumda örgütsel stres örgütsel başarısızlığa neden olan önemli bir faktör olarak değerlendirilebilir. Örgütsel tükenmişlik, bireyin, basit ve fiziksel yorgunluktan çok, yapılan iş ve çalışma düzeninin gerektirdiği aşırı olarak algıladığı zihni yük, kariyer amacından sapma ve değişime uymada kendini çaresiz hissetmesini ifade etmektedir (Koçel, 2015, s. 532).

Örgütteki bireylerin, çalışma arkadaşları, astları, yöneticileri hakkında olumsuz şekilde konuşması örgütsel dedikodu kapsamındadır (Limon, 2020). Örgütsel intikamda çalışanlar birbirlerine birden fazla şekillerde zarar verebilmekte ve iş yaşamında saldırgan davranışlar ortaya çıkabilmektedir (Cezlan, 2020, s. 173). Örgütsel mağduriyet örgütteki saldırgan davranışlar ile alakalı bir kavram olarak ortaya çıkarken çalışan ve örgüt açısından olumsuz etkiler ortaya çıkaran bir kavramdır (Tekin, 2020, s. 222). Örgütsel sahtekarlık nedeniyle ortaya çıkan güven problemi çalışanlar arasındaki ilişkilerin olumsuz yönde etkilenmesiyle sıkıntılı süreçleri beraberinde getirebilir. Örgüt itibarının zarar görmesiyle işgücü devir hızı yükselir, istihdamda zorluklar yaşanır, iş ortamında verimlilik düșer (Gökalp ve Demir Uslu, 2020, s. 265-266).

Küresel rekabet ile birlikte organizasyon yapıları ve yönetim uygulamalarında ortaya çıkan hızlı, köklü ve sürekli değişim süreci içinde çalışanların buna ayak uyduramaması, kendilerini yeni rollerinde yetersiz hissetmeleri, mevcut bilgi ve becerilerinin yetersiz hale gelmesi gibi nedenlerle örgütsel yabancılaşma kavramı ortaya çıkabilir (Koçel, 2015, s. 531). Örgütsel yabancılaşma, 
işgörenin kendini iş sürecinden dışlaması ya da sürece adapte edememesi ve iş yaşamında kendini gerçekleştirememesi neticesinde iş görenin ortaya koyduğu tepkidir (Aydın, 2020).

Kişiler arası çatışma, gruplar veya ekipler halinde birlikte çalışan iki veya daha fazla kişi arasında meydana gelen çatışmadır. Kişilik özellikleri, tutumlar, değerler, kültür dahil birçok bireysel farklılık kişiler arası çatışmaya yol açabilmektedir. Hedefler, beklentiler, değerler, önerilen uygulamalar ve bir durumun en iyi nasıl ele alınacağı konusundaki yaklaşımlarda bireysel farklılıklar kaçınılmazdır. Organizasyonda çatışmaya neden olan faktörlerin belirlenmesi, çatışma yönetimi sürecinde ana aşama olarak kabul edilmektedir (Beheshtifar ve Zare, 2013). Çatışma ile etkili bir mücadele veya yönetimi için örgütün çatışmayı orta düzeyde tutması ve bunu daha ileriye götürmemesi gerekir (Özkalp ve Kırel, 2005, s. 401).

İşletmelerde her faaliyet önce dikkatli bir şekilde yapılacak planlama ile başlamaktadır. Her planlama, yapılacak faaliyetlerin erişmek veya ulaşmak istenilen, arzu edilen durumu gerçekleştirmeye yöneliktir (Eren, 2008, s. 167). Yöneticinin planlamaya önem vermemesi, amaç ve hedefler belirlenirken kısa, orta ve uzun vadeli zaman ufukları ile işletmenin stratejilerinin göz önünde bulundurulmaması örgütsel başarısızlığa neden olabilir. Bununla birlikte çeşitli amaçlar, bunlara ulaștıracak yollar, araçlar ve imkanlar açısından seçim ve tercih yapmakla ilgili zihinsel, bedensel ve duygusal süreçlerin toplamı (Eren, 2008, s. 185) șeklinde tanımlanan karar verme süreci yöneticiler ve çalışanlar için kritik öneme sahiptir. İşletmelerde çeşitli hiyerarşik düzeylerdeki kurumsal, stratejik, yönetsel, operasyonel kararlar; bilgi ve enformasyon eksikliği, amaçlar ve sorunların net olarak tanımlanmaması, seçim kriterlerinin yetersiz olması, belirsizliğin fazla olması, çözüm alternatiflerinin birbirine çok yakın olması, risk almak istememe gibi (Koçel, 2015, s. 167) nedenlerle alınmayabilir. Kararların karar verme sürecinin aşamalarına özen gösterilmeden alınması, kararsızlık nedeniyle faaliyetlerin aksaması örgütsel başarısızlığa neden olabilir.

Günümüzde organizasyonlarda değişim gerekliliğinden çok dönüşüm ve organizasyonların yeterli hızda değişip değişmediği, sürekli değişimin nasıl sağlanabileceği, organizasyonların kendilerini nasıl "öğrenen organizasyon" haline getirebilecekleri tartışılmaktadır (Koçel, 2015, s. 783). İşletmeler klasik bir paradoksla karşı karşıya görünmektedirler: "Değişmek zorundayız, ancak değişim girişimlerimizin çoğu başarısız oluyor" (Burnes ve Jackson, 2011). Organizasyonlarda değişmeyen tek șey değişimdir, değişimlere ayak uyduramayan, esnek bir yapıya sahip olmayan, örgütsel öğrenmenin yetersiz düzeyde olduğu işletmeler örgütsel başarısızlık kavramıyla karşı karşıya kalabilecektir.

Kriz, örgütsel istikrar ve statükonun temelden askıya alınması veya bozulmasıdır (Seeger vd., 2005, s. 80). İșletmelerin çevresinde meydana gelen olayların sayısının gerek işletmenin kontrolü dışında gerekse işletmenin uyguladığı stratejilerin başarısızlığından dolayı artması kriz kavramını işletme yaşamının önemli bir parçası haline getirmektedir. Yöneticiler kriz ortamından en az zararla çıkabilmek için işletme içi ve dışı etkileşimleri hızlı ve zamanında yapabilmeli yani krizi yönetebilmelidir. Kriz yönetiminde önemli olan krizden kaçmak ya da krizi çözmek değil krizi doğmadan önlemek veya krizi örgüt açısından bașarıya dönüștürmektir (Bağdaș, Bakan ve Özyılmaz, 2015). Örgütlerde kriz yönetim sürecinin etkin bir şekilde tasarlanmaması örgütsel başarısızlığı beraberinde getirecektir.

Girişimcilik, pazardaki firsatların iş fikrine dönüştürülerek yeni iş ve işletmelerin oluşturulduğu dinamik bir süreçtir. Girişimcilik açısından amaç, girişimin kuruluş ve var oluş nedenidir. İşletme faaliyetlerinin en rasyonel biçimde sürdürülmesi girişimcinin ilgi alanına girmekte iken, yeni iş olanaklarının bulunması ve yapılacak yeni yatırımlara işletmeye yeni açılımlar sağlanması da yine gerçekleştirmesi gereken işlevlerdir. Bu işlevleri yerine getirirken girişimi başarısızlıkla karşı karşıya bırakabilecek faktörler vardır. Bu faktörler șunlardır: sermaye yetersizliği, kuruluș yerinin doğru seçilmemiş olmaması, rekabet aktörlerinin dikkate alınmaması, yetersiz planlama, yetersiz zaman, kendine aşırı güven, eğitim düzeyinin yetersizliği, yönetim becerisi ve takım oluşturamama, girișimcinin işini sevmemesi, ticaret bilgisinin yetersizliği ve hazırlıklı olmadan işe başlamaktır (Marangoz, 2016). Yeni işletmeler için kritik zorluk, başlangıç sermayesi tükenmeden önce değerli kaynaklar ve yetenekler oluşturmaktır. Yeniliğin getirdiği zorlukları atlatan eski işletmeler arasında da, rekabet ortamındaki değişimlere yeni kaynak ve yetenek kombinasyonlarıyla uyum sağlamak zorunludur (Thornhill ve Amit, 2003). 
Bir işletme, genel amaçlarına erişebilmek için stratejisini planlarken ve geliştirirken bu planları uygulamak için gerekli insan kaynağına gelecekte sahip olup olmayacağını değerlendirmelidir. Tüm planların karşılanması için kaç çalışana ya da hangi yeteneklere ihtiyaç duyulduğunu belirledikten sonra, insan kaynakları birimi, mevcut durumda işletmede kaç çalışan olduğunu ve planlanan zaman diliminde kaç personelin emekli olacağı veya başka şekillerde işletmeden ayrılacağını belirler. Bu bilgi ile insan kaynakları yöneticisi; işletmenin kaç tane daha çalışanı işe alması gerekeceği, bu çalışanların hangi niteliklere sahip olması gerektiğini veya işgücü talebini daha etkili bir biçimde karşılayabilmek için işten çıkarmanın gerekli olup olmadığını öngörebilir (Ferrell, Hirt ve Ferrell, 2017, s. 198-199). Yönetici tarafından ilgili konularla alakalı yanlış öngörüler, işletmelerde örgütsel başarısızlık nedeni olabilecektir.

İşletmeler için doğrudan gözlemlenemeyen ve kolayca ölçülemeyen maliyetlerin ortaya çıkmasına neden olan iki kavram personel devir hızı ve ișe devamsızlık oranıdır. Personel devir hızının yüksek olması, işletmeden çok sayıda personelin ayrıldığı anlamına gelmekte iken; personel devamsızlığı ise, personelin çalışması gereken yer ve zamanda iş başında bulunmaması anlamına gelmektedir (Can ve diğerleri, 2012). Üretimin aksaması, durması, personel-yönetim ilişkilerinin bozulması, ürün kalitesinin düşmesi, personelin örgüte bağlılığının azalması, kurum içi huzursuzlukların artması gibi nedenlerle arzulanan bir durum değildir. Her iki kavramda insan kaynakları yöneticileri tarafından düzenli periyotlarla takip edilmez ve gerekli düzeltici önlemler alınmaz ise örgütsel başarısızlığa neden olabilir.

Kurumsallaşma, bir işletmenin şahıslardan ayrı olarak standartlara, kurallara, uygulamalara sahip olması, çevresel değişimleri izleyen yapılar kurması, değişimlere uyumlu olabilecek örgüt yapısının oluşturulması, kendi yapısına özgü iş süreçleri ve iletişim biçimlerini bir örgüt haline getirmesi sürecidir. Kurumsallaşmanın işletmelerin sürdürülebilirliği için hayati öneme sahip olduğu bilinmektedir (Taştan, 2020). Kurumsallaşmayı, işletmeyi tamamen profesyonellere bırakmak, bir kenara çekilmek, denetim yapmamak, herkesin sözüne göre hareket etmek, işletmenin sırlarını dışarıya aktarmak, bir sürü danışman toplamak gibi algılayan aile işletmelerinin yaşamları genelde kısa olmaktadır. Örgütsel başarısızlığın temel nedeni aile işletmelerinin kurumsallaşması sırasında aile yönetimi ve işletme yönetimi arasındaki ilişkilerin profesyonelleşememesi, işletmelerin hala geleneksel yöntemlerle idare edilmeye çalışılmasıdır. Bununla birlikte gelişi güzel yanlış kurumsallaşma uygulamaları işletmeleri hantallığa itebilir ve bu yüzden işletmelerdeki yaratıcı gelişme yok edilebilir (Atilla, 2016, s. 91-94).

Vekalet yaklaşımı, işletmenin sahipliğinin yönetimden ayrılmasının işletmenin sahiplerinin isteklerinin dikkate alınmasına neden olacağını öne süren örgütsel kontrol ile ilgili fikirlerdir. Ahlaki tehlike sorunu ve olumsuz seçim, işletmeyi örgütsel başarısızlıkla karşı karşıya getirebilir. Ahlaki tehlike sorunu, işletme sahiplerinin işletme ile ilgili bilgilere üst düzey yöneticiler kadar sahip olmamalarını, üst düzey yöneticilerin kişisel menfaatleri yönünde faaliyet göstermelerine sebep olma sorunudur. Olumsuz seçim ise, hissedarların üst düzey yöneticileri işe aldıklarında onların önceliklerini ve yetkinliklerini belirlerken sınırlı yeteneklerinin olmasından kaynaklanmaktadır (Karabulut, 2020). Kurumsal yönetim, bir işletmenin yerel ve uluslararası kanunlara, şeffaflık ve hesap verebilirlik gerekliliğine, etik normlara, çevresel ve sosyal davranış kurallarına uyduğu anlamını taşımaktadır (Varol, 2019, s. 67). Kurumsal yönetim ilkeleri doğrultusunda faaliyetler sürdürmek, yönetim kurullarını güçlendirmek, uzun dönemde işletmelerin başarılarını arttıracak ve devamlılığını sağlayacaktır. Kurumsal yönetim ilkeleri, işletme tarafından yeterince benimsenmediyse paydaşların bu yöndeki beklentileri karşılanamayacak, örgütsel başarısızlık beraberinde ortaya çlkabilecektir.

\section{Üretim Fonksiyonu}

İşletmelerin temel amaçlarından biri uzun vadede yaşamlarını sürdürmek ve kar elde etmektir. Bunu sağlayabilmek için de daha az emek, zaman ve maliyetle yüksek verimlilik düzeyinde faaliyette bulunurlar. Üretim en genel tanımıyla, insan ihtiyaçlarını karşılamak üzere üretim faktörlerinin (doğal kaynaklar, emek, sermaye ve girişim vb.) uygun ortamda bir araya getirilerek mal ya da hizmet haline dönüştürülmesidir. Kar amacı gütsün ya da gütmesin tüm örgütlerde müşteri istek ve beklentilerini karşılayacak mal ve hizmetlerin üretilmesi işletmenin varoluş sebebidir. $\mathrm{Bu}$ gerçekleştirilemediği takdirde işletmenin sürekliliği söz konusu değildir. Uzun vadeli bir yaşamda örgütlerin üretim faaliyetinde bulunurken başarısızlıklarla karşılaşma ihtimalleri çok yüksektir. 
İşletmelerin yoğun rekabet koşullarında başarılı olabilmesi için yöneticilerin zamanında, doğru ve isabetli kararlar alması gerekir. Sürekli değişen çevre koşulları karşısında üretim yöneticilerinin bu değişikliklere yeteri kadar uyum sağlayamaması örgütsel başarısızlığın en önemli nedenlerinden biridir. Müșteri istek ve beklentilerinin hızla değișmesi, küresel pazarlarda yașanan rekabet, hizmet sektörünün gelişimi, ulusal ya da uluslararası pazarlarda işletmelerin rakiplerine kıyasla daha düşük maliyetle daha kaliteli ürünler sunması, üretimde kullanılan kaynakların sınırlı olması vb. faktörler örgütsel başarısızlıkta rol oynayan çevresel koşullar arasında yer almaktadır. Değişen çevre koşullarına ayak uyduramayan örgütlerin varlığı tehdit altına girecektir. Aynı pazarda benzer tüketici gruplarına yönelik mal veya hizmet sunan tüm işletmelerin yeni teknolojileri kullanmasına karşın, belli bir işletmenin yenilikleri takip etmemesi durumunda işletmenin ürünleri kalite ve fiyat bakımından rekabet edemeyecek ve müşteriler diğer işletmelere yönelecektir. Örgütlerde sınırsız kaynak kullanımıyla müşteri doyumu sağlanabilir. Oysa ki doğada olduğu gibi sistem içinde de üretim kaynakları kıttır. Bu kaynakların sınırsız kullanımı mümkün değildir. İşletmenin elindeki mevcut kaynakların etkin ve verimli kullanılmaması durumunda örgütsel başarısızlık da kaçınılmaz olacaktır. Dolayısıyla, üretim kaynaklarının verimli kullanımı örgütün amaçlarına ulaşabilmesi açısından zorunluluk oluşturmaktadır. Çünkü düşük maliyetle ve yüksek kalitede üretim sadece kaynakların verimli kullanılmasıyla mümkün olabilecektir. Üretim yönetimiyle, kaynakların en etkin bir biçimde kullanılması, kayıpların en aza indirilerek verimli çalışması ve kalite yönünden istenilen seviyeye çıkarılması hedef alınmaktadır (Tekin, 2012, s. 6).

Doğal felaketler örgütlerin çevrelerine uyum göstermeleri durumunda da örgütsel faaliyetleri belli oranda etkilemektedir. Doğal felaketlere karşı hazırlıklı olmak, kaynağı doğal felaketler olan krizin zararını önemli ölçüde azaltmaktadır (Genç, 2004, s. 340). Doğal olarak ortaya çıkan deprem, sel gibi felaketler örgütün denetimi dışında meydana gelen olaylardır. Örgütleri büyük ölçüde etkileyen etmenler arasında yer alan bu faktörler, örgütün kriz ortamına girmesine sebep olmaktadır (Akdağ, 2001, s. 40). Bu doğrultuda, doğal felaketlere karşı gerekli önlemlerin alınması, afeti önleme olanağının olmamasına karşın, afet sonrası oluşacak olumsuzlukları önlemeyi veya olası zararları azaltmak açısından önemlidir. Satıcının hammadde ve malzemeyi geç göndermesi, işgücünden kaynaklanan hatalar, işgücü dönüşü, iklim, enflasyon, ekonomik durgunluk gibi koşullar tesadüfi dalgalanmalara örnektir. Üretim sisteminin birçoğunun kendi denetimi dışındaki bu tesadüfi dalgalanmalar çerçevesinde çalışması gerekir. Gerçekte üretim süreçlerinde dalgalanmalar tesadüfi değil, kuraldır ve dalgalanmaların sistem üzerindeki etkisinin azaltılması önemli bir yönetim görevidir (Üreten, 2006, s. 10).

Üretim fonksiyonu, işletmenin genel yönetimi ve organizasyonu içinde önemli bir yer tutmaktadır. Örgütün alt sistemleri olan pazarlama, finansman, muhasebe ve diğer işletme fonksiyonlarıyla sürekli bir ilişki ve etkileşim içerisindedir. Örneğin üretim fonksiyonu; işletmeler için gerekli olan işgücünün istihdam edilmesinde insan kaynakları yönetimi fonksiyonu, üretim için gerekli olan her çeşit hammadde, ürün, malzeme, donanım ve hizmetlerin temin edilmesinde satın alma fonksiyonu, üretilen mal veya hizmetlerin tüketiciye ulaştırılmasında pazarlama fonksiyonu ile uyumlu bir şekilde çalışmalarını sürdürmektedir. Örgütün herhangi bir fonksiyonunda meydana gelen bir gecikme diğer fonksiyonların faaliyetlerini de olumsuz yönde etkileyecektir. Dolayısıyla başarılı bir üretim sistemin kurulabilmesi için öncelikle katılımcı ve destekleyici bir yönetim anlayıșı liderliğinde örgüt kültürünün oluşturulmasına ihtiyaç vardır. Bu sağlanamadığı takdirde örgütsel başarısızlık kaçınılmaz olacaktır. Bir örgütün kültürü ne kadar güçlü ise, örgüt üyelerinin davranışları daha büyük ölçüde kontrol edilebilmektedir. Çoğunlukla güçlü bir örgüt kültürü, üyeler arasında artan işbirliği, dayanışma ve örgüte bağlllıkla sonuçlanır. Bunun sonucunda yüksek performans, motivasyon artışı, işten ayrılma oranlarında düşüş, kuralların ve bürokrasinin azaldığı kontrol ve öğrenme gibi birtakım süreçlerin içselleştirildiği bir çalışma ortamı beklenilmektedir (Köksal, 2007, s. 52).

Günümüzün rekabetçi küresel ortamında örgütler, yetenekli çalışanları cezbetme, işe alma ve elde tutma zorluklarıyla karşı karşıyadırlar. Bununla birlikte örgüt çalışanlarının yenilikleri benimsemeye istekli olması ve örgüte karşı yüksek derecede bağlılık geliştirmeleri örgütlerin karşı karşıya kaldığı diğer önemli zorluklardır. Bu zorlukların üstesinden gelemeyen örgütlerde örgütsel başarısızlık söz konusudur. Bunun için örgütler; çalışanların karar verme sürecine dahil edilmesi, kişisel ve mesleki yeteneklerini geliştirmeleri için eğitim imkanları sağlaması, yeterli ücret ve çeşitli 
sağlık programları gibi çeşitli işyeri uygulamalarını benimsemeye odaklanmaktadırlar. Örgüt çalışanlarının kişisel gelişiminin sağlanabilmesi için önce onların yeteneklerinin keşfedilmesi ve daha sonra da keşfedilen bu yeteneklerden yüksek oranda yararlanılması gerekir. İnsan faktörüne verilen değer arttıkça çalışanların verimliliği artacak, moral ve motivasyonu yükselecektir. Bunun sonucunda çalışanların yeteneklerinin en yüksek düzeyde kullanımı sağlanacaktır. Böylece daima verimli çalışan işçi daha çok üretecek ve işletme verimliliği artacaktır. Bu nedenle çalışanların eğitilerek motive edilmesi, etkili bir şekilde yönlendirilmesi, bilgi, beceri ve yeteneklerinin geliştirilmesi önemlidir. Çünkü çalışanların motive edilerek kişisel yeteneklerinin geliştirilmesi durumunda çalışanlar kendilerine sunulandan çok daha fazlasını örgüte kazandıracaktır.

Kalitesiz hammadde ve malzeme kullanımı, taşıma sistemlerinin yanlış seçimi, depolama şartlarının yetersiz ve elverişsiz olması, kötü yerleşim düzeni, iş akışının düzensiz olması, işgücü eğitiminin yetersiz olması vb. nedenlerden dolayı işletmelerde atık malzeme oranı artmaktadır. İşletmelerde üretim faaliyetleri sonucu ortaya çıkan atık malzeme oranının yüksek olması ise işletmenin verimliliğinin düşmesine neden olan önemli etkenlerden biridir. Bu durum işletmenin başarısızlığ noktasında kilit rol oynayabilmektedir. Bu sorunların iyileștirilmesine yönelik yöneticilerin malzeme kullanımını en aza indiren ürün tasarımı, iş akış sisteminin malzeme tasarrufu sağlayacak şekilde düzenlenmesi, depolama şartlarının sağlıklı ve güvenli hale getirilmesi gibi bir takım çözüm önerileri geliştirmeleri önerilebilir. Bunların gerçekleştirilmesi sırasında işletmede atık malzeme oranı azalacak, buna karşılık üretim miktarı artacağından verimlilik artışı da gerçekleşmiş olacaktır.

Bir imalat veya hizmet işletmesi için kuruluş yeri seçimi ve kapasitesi örgütün başarı veya başarısızlığı üzerinde güçlü etkileri olan stratejik bir karardır. Kaynakların uzun dönemli tahsisini gerektiren bu kararların birçok durumda değiştirilmesi zor ve hatta imkansız olduğu için yöneticilerin kuruluş yeri kararını vermeden önce potansiyel kuruluş yerlerine ilişkin ayrıntılı bir analiz gerçekleştirmeleri gerekir. İşletmenin kuruluş yeri seçilirken maliyetleri minimum kılan aday kuruluş yeri optimum kuruluş yeri olarak belirlenmelidir. Böyle yapılmadığı takdirde işletme yanlış yerde kurulmuş olur ki, bu nedenden kaynaklanan hammadde temini, taşıma maliyetleri, pazarlama, ulaşım ve altyapı sorunları gibi birçok sorunların giderilmesi için harcanması gereken maliyetlerin yüksekliği, işletmede verimliliği olumsuz etkileyen örgütsel başarısızlık riskini artıran bir unsur olarak görülmektedir. Kuruluş yerinin seçiminde göz önüne alınması gereken faktörler işletmeden işletmeye farklılık göstermektedir. Hammadde tüketimi yüksek olan işletmelerin hammadde kaynağına yakın olması, pazara kolay ulaştırılması gereken ürün üreten işletmelerin ise pazara yakın olması önemlidir. Ancak mutlaka işletmenin hammaddenin işletmeye taşınması, mamulün pazara taşınması ve üretimin gerçekleştirilmesi için gerekli maliyetleri minimize edecek bir kuruluş yerini belirlemesi önerilmektedir. Aynı şekilde, değiştirilmesi zor olduğu için etkisi sürekli olan bir diğer örgütsel bașarısızlık riskini artıran unsur da kapasitedir. İșletmenin kapasite planlaması da başlangıçta bilimsel verilere dayalı analizler yapılarak uygun büyüklükte belirlenmiş olmalıdır. Aksi takdirde, özellikle gereğinden daha büyük kapasite ile kurulmuş olan işletmelerde atıl kapasite oluşacak, bu ise birim maliyetlerin artmasına, verimliliğin ise düşmesine neden olacaktır. Bu nedenle işletmelerin tam kapasite olmasa bile teorik kapasiteye mümkün olduğunca yakın kullanım oranlarını yakalaması gerekmektedir. Öte yandan, gereğinden daha küçük kapasite ile kurulmuş olan işletmelerde ise belli dönemlerde talebin karşılanamaması durumu ortaya çıkacak, bu ise müşteri memnuniyetsizliğine, pazar payının küçülmesine ve müşterilerin bir kısmının kaybedilmesine yol açacaktır.

İşletme kurulurken hangi üretim teknolojisinin ve makine teçhizatının kullanılacağına karar verilmesi örgütlerin başarısını etkileyen önemli unsurlardandır. İşletmelerde pahalı ve gereksiz ileri teknoloji seçilmiş olması maliyetlerin büyük oranda artmasına, tam kapasite çalıştırılamamaları nedeniyle kapasite boşluğu maliyetlerine ve vasıflı işgücü maliyetlerinin artmasına neden olacaktır. Diğer taraftan işletme teçhizatının uygun seçilmemiş olması durumunda ise gerekli bakım-onarım işlerinin zamanında yapılmaması sorunuyla karşılaşılacaktır. Bakım onarım işlemi geciktirilen ya da uygun yapılmayan makine teçhizatın hem ekonomik ömrü kısalacak ve hem de performansı düşecektir. Üretim hattında beklenmeyen zamanlarda meydana gelen duraklamalar üretim kayıplarına ve hatta iş kazalarına neden olabilecektir. Bu konularda bilinçli bir yönetim anlayışı ve planlı bir yaklaşımla alınamayan stratejik kararlar örgütü başarısızlığa götürmede etkili olabilmektedir. Sistemin koruyucu bakım faaliyetleriyle makine arızalarının ortaya çıkmaması ya da minimize edilmesi yönünde tedbirler alınabilir. 
Kötü çalıșma koşulları örgütleri başarısızlığa götüren faktörlerden birisidir. Çalışma ortamının gürültülü, aşırı soğuk ya da sıcak, yetersiz aydınlatma ve havalandırma vb. fiziksel koşullarının uygunsuzluğu, aşırı ve uzun çalışma saatleri, ergonomik şartlara uyulmaması nedenlerinden dolayı çalışanlarda yorgunluk ve motivasyon eksikliği görülmektedir. Bu durum çalışanların iş yaşam kalitesinin düşmesine ve dolayısıyla da örgütsel başarısızlık yaşanmasına neden olmaktadır. İş̧ yaşamının kalitesi bir taraftan çalışanların refah ve memnuniyetini etkilerken bir taraftan da onların verimlilikleri üzerinde etkili olmaktadır. Çalışanların kendi iş arkadaşlarıyla olan ilişsileri, yönetimin kalitesi, yönetimin tüm çalışanlara adil davranması, içinde bulunulan çevrenin koşulları, çalışma koşulları, ücretlendirme sistemleri çalışanların iş yașam kalitesini belirleyen unsurlardır. Bütün bu unsurlar; çalışanın refahı, işten aldığı hazzı, tatmini ve doyumunu etkilemekle kalmamakta aynı zamanda onların daha verimli çalışmalarını da olumlu yönde etkilemektedir.

Günümüzde örgütsel başarısızlığın önemli faktörlerinden birisi de işletmelerin müșterilerine etkin bir servis sistemi yönetimi oluşturamamalarıdır. İşlenecek olan parçanın iş istasyonlarına geliş zamanlarının ve bunların istasyonlarda işlem görme sürelerinin değişken olması nedeniyle, istasyon doluyken gelen müşterilerin beklemesi ya da istasyon boşken müşteri gelmemesi söz konusu olabilir (İlyasoğlu, 1983, s. 113). Bu durumda, müşteriler işlem görmek için beklemek zorunda kalabilirler, başka bir işletmeyi tercih edebilirler, programlar aksayabilir ya da kaynaklar atıl kalabilir ve tüm bu sorunlar, işletmeye birtakım maliyetler yükler. Bu tür sorunlarla karşılaşan yöneticiler, gelen siparişleri işlemek için gerekli iş istasyonu sayısının belirlenmesini sağlayacak bekleme hattı analizine ihtiyaç duyarlar. Bekleme hattı sayesinde aksama ve tıkanıklık sonucu katlanılacak maliyetlerin düşmesi sağlanacak, müşteri doyumu yükselecektir (Üreten, 2006, s. 106).

Müșterilerce beğenilmeyen, talebi olmayan ürünlerin üretimi örgütü başarısızlığa götürecektir. İşletmeler mal ve hizmet üretmek, bunları tüketicilere ulaştırmak, satmak, elde ettikleri gelirle üretim faaliyetlerini devam ettirmek ve ortaklarına bir takım kar payı dağıtmak durumundadır. Bu nedenle ürünü tüketici tarafından kabul görmeyen bir işletmenin piyasada başarılı olma şansı bulunmamaktadır. Hele ki son derece yoğun rekabetin yaşandığı günümüzde tüketiciler de oldukça bilinçli ve seçici davranmaktadır. Tüketici işletmenin ürününü beğenmediği takdirde rahatlıkla başka bir işletmeye gidip kendi arzuladığı özellikteki başka bir ürünü satın alma imkanına sahiptir. Bu nedenle ne üretileceğinin seçilmesi ve bunun tüketici ihtiyaç ve beklentilerine uygun bir şekilde tasarlanması örgütsel başarının elde edilmesinde önem taşımaktadır.

\section{Pazarlama Fonksiyonu}

Pazarlama fonksiyonu, müşteri istek ve ihtiyaçlarını en uygun şekilde karşılamak üzere üretilen mal veya hizmetlerin üreticiden müşteriye ulaşımını, sunumunu ve satışını sağlamaktadır. İşletmenin diğer fonksiyonları görevlerini ne kadar iyi yaparlarsa yapsınlar, ürünü pazarda kabul görmeyen örgütlerin başarı şansı bulunmamaktadır. İşletmelerde pazarlama fonksiyonu üretici ile tüketici arasında köprü görevi üstlenerek müșteri tatmininin sağlanmasında önemli bir rol oynamaktadır. $\mathrm{Bu}$ nedenle, günümüzün yoğun rekabet ortamında pazarlama faaliyetleri hayati bir öneme sahiptir. Modern pazarlama anlayışının odak noktası tüketici olduğuna göre, işletme pazara dönük eylemlerinde tüm örgütsel faaliyetlerini tüketicinin istek, ihtiyaç ve beklentileri üzerinde yoğunlaştırmak zorundadır. Bu ise pazarlama yöneticilerinin hedef pazarın özelliklerini ve bu pazardaki tüketicileri iyi tanımasını gerektirmektedir. Bir pazarlamacı hangi pazarda bulunursa bulunsun, hedef pazara uygun mal ve hizmetleri işletmenin amaçları doğrultusunda etkin bir şekilde sunamadığı takdirde örgütü başarısızlığa götürebilir. Bir pazarlama yöneticisi aynı ihtiyacı gidermede farklı kişilik yapısı, yaşam tarzı, demografik, sosyo-kültürel ve ekonomik özellikteki tüketicilerin farklı mal ve hizmet özelliklerinden tatmin olacaklarını bilmeli ve buna uygun stratejiler geliştirmelidir. Ayrıca pazarlama yöneticisi, hedef pazar bölümü ya da bölümlerindeki tüketicilerin tutumlarını ölçebilir ve değerlendirebilirse, onların satın alma davranışlarını tahmin ederek belirli başarılar sağlayabilir (İslamoğlu ve Altunışık, 2017, s. 149).

Pazarlama yönetimi hedef pazara uygun ürün ile ilgili kararlar alırken, ürün kalitesi, ürün özellikleri, ürün dizaynı ve ürün standartlarına uygunluk gibi kriterleri göz önünde bulundurmak durumundadır. Örneğin, fiziksel özelikleri bakımından kaliteli olmasına rağmen kullanıcıya düşük faydalar sağlayan ve kötü dizayn edilmiş birçok ürünün pazarda başarılı olma şansı yok denecek 
kadar azdır. Tüketiciye sağlayacağı fayda ve kalite yanında, ürünün göze hitap eder tarzda ve psikolojik açıdan da alıcısını tatmin edebilecek biçimde dizayn edilmesi gerekmektedir (Altunışık ve diğerleri, 2016, s. 313). Fiyatlandırma kararları, işletmenin satışlarını, kârını ve dolayısıyla da başarısını etkilediği için pazarlama yöneticileri tarafından dikkatle kullanılması gereken etkili bir pazarlama aracıdır. Eğer işletme piyasada var olma amacını, pazardaki pozisyonunu dikkatli belirlerse ve buna bağlı olarak fiyatlandırma stratejisini doğru oluşturursa, işletme hedeflerine daha rahat ulaşma imkânına sahip olur (Kotler ve Armstrong, 1997, s. 496). Pazarlama yöneticilerinin müşterilerine uygun fiyatlı mal ve hizmet sunmak, uygun ödeme yöntemleri geliştirmek, maliyetleri göz önüne alarak fiyat belirlemek, piyasa fiyatlarını takip etmek ve rekabet için uygun fiyat belirlemek gibi fiyatlandırma ile ilgili görevleri bulunmaktadır. Pazarlanan bir ürünün başarılı bir şekilde satılabilmesi için müşterinin istediği yerde ve zamanda uygun miktarda hazır bulundurulması gerekir. Bu durumun sağlanabilmesi ancak etkili bir dağıtım kanalıyla mümkün olabilir. İşletmeler piyasadaki en iyi ürünü üretme ve bunları tanıtma imkanına sahip olsalar bile, eğer tüketici ona ulaşmakta zorluk çekiyorsa, o ürüne karşı isteği kırılabilir ve alternatiflerine yönelebilir. Bu nedenle örgütün pazarda başarılı olabilmesi için uygun bir dağıtım kanalı seçilerek, ürünün müşterilere ulaştırılması gerekir. Bir işletme tüketici istek, ihtiyaç ve beklentilerine uygun mal veya hizmetlerini başarılı bir tutundurma programı ile tüketicilere ulaştırarak çok sayıda müşteri edinebilir. Hedef pazardaki tüketiciler işletmenin ürün veya markalarını tanımıyorsa, sunduğu faydalardan haberdar değilse işletmenin ürün ya da markasının yerine rakip ürün veya markaları tercih edebilecektir. Diğer bir ifadeyle, işletme etkin bir tutundurma karması araçlarıyla hedef kitleye ulaşamamışsa örgütün pazarlama programının başarı şansı da olmayacaktır. Pazarlama yönetimi mal ve hizmetin tanıtımında yoğun reklam kampanyaları, satış geliştirme, doğrudan pazarlama ve halkla ilişkiler gibi çeşitli iletişim araçlarını kullanarak pazardaki müşterilerine ulaşabilir. Böylece işletme sürekliliğini sağlayabilir ve rekabet üstünlüğü elde edebilir.

Teknolojide meydana gelen değişimler sonucu ürün yaşam süreleri giderek kısalmaktadır. Günümüzde işletmeler ürünlerini daha hızlı bir şekilde piyasaya sunmakta, müșterilerin yeni ürün veya hizmetlere olan talepleri artmaktadır. Dolayısıyla bu yeni ürün ve hizmetleri hızlı bir şekilde geliștirip sunamayan, ürün ve hizmetlerinde yenilik yapamayan işletmelerin rakipleri karşısında sürdürülebilir rekabet avantajı kazanmaları mümkün olmamaktadır. Ayrıca işletmelerin müşteri istek ve ihtiyaçlarını yeni gelişmelere uygun olarak tanımlayamamaları da örgütlerde başarısızlığa neden olabilmektedir. Bu nedenle pazarlama yöneticilerinin tüketicilerin ihtiyaç duydukları mal ve hizmetleri fark ederek geliştirilmesini sağlamaları gerekmektedir.

İşletmenin amaçlarından biri de müşterilerine yüksek kaliteli mal ve hizmet sunumuyla müşteri memnuniyetinin sağlanması sonucu gelirlerini artırmaktır. Bu bağlamda çalışanların tatmin edilmesi örgütün başarısı için son derece önemli olmaktadır. Çalışanlar sosyal ve ekonomik anlamda tatmin edilemezse, işinden ve işyerinden memnun olmayan mutsuz çalışanlar ortaya çıkacaktır. Bunun sonucunda örgütsel başarısızlık ve dolayısıyla mali kayıplar söz konusu olacaktır. Bir çalışanın tatmin düzeyi ne kadar yüksek olursa, motivasyon düzeyi de o kadar yüksek olacak ve ürettikleri mal ve hizmet kalitesi de artacaktır. Bu durumda dış müșteri tatmini de sağlanacaktır. İşletmede insan kaynaklarını başarılı ve etkili bir şekilde yönetmek isteyen işletmeler, müşterilerine yönelik yapmış oldukları ödüllendirme programlarını, işletme çalışanlarına da uygulamaları gerekmektedir. Bu bağlamda, işletme çalışanlarına müşteri gibi davranmak ve onları uzun dönemde işletmede tutmaya çalışmak, etkili ve önemli bir yönetim uygulamasıdır (Gel, 2007, s. 78; Yıldırım, 2012, s. 14).

\section{Muhasebe ve Finans Fonksiyonu}

İşletmeler, varlıklarını sürdürmek ve korumak, kar elde etmek ve topluma hizmet etmek amacıyla kurulurlar. Fakat işletmelerin muhasebe hileleri ve aldatmalarının, ölümcül kazaların, çevresel afetlerin neden olduğu kurumsal başarısızlıkları, tüketici isteklerine cevap verememeleri, teknolojik gelişmeleri takip edememeleri zaman zaman örgütsel başarısızlığa uğrayabileceklerini bariz bir biçimde görünür kılmıştır (Gillespie ve Dietz, 2009, s. 127).

İşletmelerin finansal anlamda başarısızlık yaşadığını çok sayıda göstergeyle tespit etmek mümkündür. Bunlar; işletmenin sermayesinin \%50'sinin kaybedilmesi, iflas etmiş olması, işletmenin sahip olduğu varlıklarının \%10’unun kaybedilmiş olması, işletmenin borçlarını ödemekte zorluk yaşaması, işletmenin üretiminin durdurulması, işletmenin borçlarının varlıklarının toplamının 
üstüne çıkması, işletmenin üst üste üç yıl zarar beyan etmiş olması olarak sıralamak mümkündür (Aktaş vd. 2003, s. 12).

İşletmelerde finansal açıdan başarısızlık iki ana başlık altında incelenebilir. Bunlar, ekonomik başarısızlık ve finansal başarısızlıktır.

Ekonomik başarısızlık, işletmelerin sermaye maliyeti ve karlılıkları ile alakalı bir kavramdır. İşletmelerin sermaye maliyetleri karlılıklarının üzerinde ise bu işletmeler ekonomik yönden başarısız işletme olarak kabul edilirler (Dağlı, 1994, s. 130). Ekonomik yönden başarısızlık içerisinde olan işletmelerin borç kullanarak elde ettiği kaynakları; sermaye maliyetini düşürmek için ve de nakit akışlarını arttırıcı önlemler uygulamak için kullanabilir (Sayılgan, 2017, s. 461).

Ekonomik olarak başarısız olan işletmeler artan işletme riski nedeniyle sermaye maliyetini arttırmaktadır. Bu sebeple faiz giderlerinde artış olması karlılığı azaltır. Böylece de ekonomik başarısızlık yanında finansal başarısızlığı da getirmektedir (Sayılgan, 2017, s. 462). Finansal başarısızlık işletmelerin finansal zorunluluklarını yerine getirirken güçlük çekmesi veyahut bu zorunlulukları sürdürememesi olarak ifade edilmektedir (İçerli ve Akkaya, 2006, s. 414). Diğer bir tanıma göre ise, işletme politikaları, alınan finansal kararlar ve işletmenin başka alanlarında meydana gelen başarısızlıklar sonucunda oluşan hedeflere ulaşamama durumunu ifade eder (Okka, 2009, s. 928). Yani işletmenin tüm fonksiyonlarıyla alakalı olarak karş̧laşılan problemleri çözümlenmediğinde, işletme hedeflerine ulaşamaz ve bu durumda başarısızlık söz konusu olur. İşletmenin bu başarısızlığının nakit çıkışlarını arttıran ya da nakit girişlerini azaltan etkileri olmaktadır. İşletmenin belirlediği hedeflere ulaşmadaki başarısızlığı sonucunda finansal başarısızlık söz konusu olur (Sayılgan, 2017, s. 463). İşletmenin likidite yetersizliği nedeniyle borçlarını ödemekte sıkıntı çekmesi teknik başarısızlık olarak tanımlanırken, işletmenin yasal yola başvurarak faaliyetini sonlandırması durumu ise iflas olarak tanımlanır (Brigham ve Gapenski, 1994, s. 1015). Teknik anlamda başarısızlık yaşayan işletmelerin durumunun kötüye gittiği söylenebilir ve çok sık olmasa da bu tür başarısızlıklar iflas ile sonuçlanmaktadır (Altman ve Hotchkiss, 2006, s. 5).

İşletmelerde örgütsel başarısızlı̆ı̆n ortaya çıkmasında çeşitli nedenler etkili olmaktadır. Fakat işletmeler istenilen hedeflere başarı ile ulaşmak isterlerken öncelikle işletmenin finansal açıdan başarısını göz önünde bulundurmaktadırlar (Özalp ve diğerleri, 2006, s. 125). İşletme faaliyetlerinin her aşamasında ortaya çıkabilecek olan örgütsel başarısızlığın muhasebe ve finans birimini ilgilendiren nedenleri, işletme içi nedenler ve işletme dışı nedenler olarak sinıflandırmak mümkündür.

İşletmenin faaliyetleriyle alakalı olarak ortaya çıkan, işletmenin kontrol edebileceği nitelikte olan nedenler işletme içi finansal başarısızlık nedenleridir. İşletme içi finansal başarısızlıkların nedenleri genel olarak yönetimin hatalı ve yetersiz olması, aşırı şekilde borçlanma, yetersiz işletme sermayesi ve de yetersiz nakit akışı olarak dört başlık olarak incelenebilir. Bunlara örnek olarak; işletme sermayesinin az olması, faaliyet giderlerinde meydana gelen artış, denetim sisteminin zayıf olması, bütçe kontrol sistemlerinin etkin olmaması, finansal performans bilgilerinin doğru olarak olușturulmaması, büyüme planlarında oluşan yetersizlikler, bölümler arasındaki koordinasyon yetersizliği, satışlardaki sürekli azalış, maliyetlerdeki aşırı artış verilebilir (Longenecker ve diğerleri, 1999, s. 504; Poyraz, 2008, s. 534).

Yapılmış olan bir araştırmada ise; finansal gösterge oranlarından olan cari oran ve nakit oranının artması, asit test oranının azalması, işletme sermayesi devir hızının faaliyetlerden elde edilen kaynakların borçları karşılama oranının azalması, faiz ve vergi öncesi karın aktif varlıklara oranının artması başarısızlık olasılığını anlamlı bir şekilde arttırdığı gözlemlenmiștir. Bunların yanı sıra, finans yöneticileri ve diğer birim yöneticilerinin 'doğru' kurumsal yönetim uyguladığı işletmeler uzun dönemde başarılı olma şansını arttırmaktadır (Ersan ve Ertan, 2018, s. 203).

İşletmenin finansal başarısızlığı üzerinde küresel finansal krizin de anlamlı şekilde etkisi olduğu görülmektedir. Diğer yandan işletmenin yaşının artması yazında yapılmış tüm modellerde olduğu gibi işletmenin finansal başarısızlık olasıllğını azalttığı gözlemlenmiştir (Ersan ve Ertan, 2018, s. 203). 
İşletmelerin finansal açıdan başarısız olmalarındaki en önemli paya sahip olan kişiler işletmenin finansal kararlarını veren yönetimdir. Bu nedenden dolayı işletmenin finansal yönetim ekibinin en uygun kararı doğru zaman içerisinde verebilecek gerekli bilgi birikimine ve yeteneğine sahip olan kişilerden oluşması gerekmektedir. Bir başka açıdan da finansal yöneticiler, sermaye, işletmenin kar dağıtım, stok, yatırım ile personelinin sorumlulukları, yetkileri, maaşları gibi mevzularda diğer birimlerin yöneticileri ile fikir birliği ve uyum içinde olması ve de bu mevzularda karşılarına çıkan sorunları çözebilecek yeteneğe sahip olmaları gerekmektedir (Taşpınar Cengiz ve diğerleri, 2015, s. 65).

İşletmenin üst yönetimi tarafından verilmiş olan kararları incelenen bir araştırmada işletmeyi başarısız olmaya iten kararları vermiş olan yöneticilerin, ilk öncelikle sorunu doğru belirlemek, alternatif çözümler araştırmak yerine problemle ilgili kararı verip daha sonra bu kararını dayanak gösterecek delilleri bulmaya çalıștıkları görülmüştür (Nutt, 2002). Finansal yöneticilerin karar verebilmeleri için gerekli olan bilgilere ulaşabilmeleri hususunda yetersiz oldukları ve tam olmayan bilgi ve tecrübelerle verilmiş olan kararların tatmin edici neticelere ulaştırmada yeterli olmadığ sınırlı rasyonellik teorisinde belirtilmiştir (Simon, 1997, s. 291-293).

İşletme dışı finansal başarısızlık nedenleri ise işletmelerin dış çevre ile olan iletişiminden kaynaklanan ve de yöneticilerin kontrolü dışında gelişen nedenlerdir. Bunlar; makroekonomik çevre, politik ve yasal çevre, toplumsal çevre ile doğal çevredir (Sayılgan, 2017, s. 465).

İşletmeler, bulunduğu çevre ile etkileşim içerisindedirler. Rekabet şartları dikkate alınarak yüksek performans gösterenlerin ödüllendirildiği, düşük performans gösterenlerin ise cezalandırıldığı ve etkililik ile verimlilik temeline dayanarak faaliyetlerin yürütüldüğü çevre olan makroekonomik çevre de kaynak temini en önemli husustur. Kıt kaynaklara ulaşmada başarılı olabilen, az kaynak kullanımı sağlayarak yüksek performans gösterebilen ve finansman kaynakları üzerinde kontrolü elinde tutarak diğer işletmeleri kendisine bağlayabilen işletmeler daha düşük örgütsel başarısızlık riskine maruz kalmaktadır (Çivici ve Kale, 2009, s. 96; Scott, 2003'ten aktaran Taşdöven, 2013, s. 424).

Kaynak bağımlılı̆̆ı teorisi işletmenin makroekonomik çevresindeki bağlarını inceleyip açıklayan bir teoridir. Bu teori işletmelerin yaşam döngüleri boyunca varlıklarını devam ettirebilmeleri nedeniyle iletişim içinde oldukları çevrelerinden fon elde etmenin gerekli olduğundan ve işletmelerin fon sağlamasının hangi şartlar altında gerçekleştiğinden bahsetmektedir. Teoriye göre, işletmelerin yaşamlarını sürdürebilmeleri için gerekli olan fonların tamamını ellerinde bulundurabilmelerinin imkansız olduğunu savunmaktadır. İşletmeler ihtiyaç duydukları fonların belli bir kısmını çevrelerinden elde etmeleri gerekmektedir. İşletmelerin yaşamını başarılı bir şekilde devam ettirebilmesi fonlarının ne kadarının elinde olduğu ve çevresinden bu fonları sağlama yeteneğine ne derecede haiz olduğuyla doğrudan bağlantılıdır (Pfeffer ve Salancik, 1978, s. 108). Hammadde, sermaye, emek, bilgi ve donanım gibi yaşamla ilgili fonlara sahip olması işletmenin öbür işletmelere olan bağımlılığını azaltacağı gibi yaşama şansını da arttıracaktır. Yani diğer işletmeleri kendine bağlayabilme hususunda avantajlı olan işletmeler, çevrelerinde bulunan işletmelere kaynak temin edebilen ve diğer işletmelerin de güvenini kazanabilen işletmelerdir. Bahsedilen avantaj işletmelerin aynı zamanda başarısız olma olasılıklarını da düşüren bir faktör olarak karşımıza çıkmaktadır. Literatürdeki çalışmalar göstermektedir ki, işletmenin başarısı ve yaşamına devam edebilmesi sahip olunan fonlar ve önemli kaynaklara ulaşabilme yeteneği ile doğru yönlü bir ilişkiye sahiptir (Sheppard, 1995, s. 28; Meydan, 2010, s. 17).

\section{Sonuç ve Öneriler}

İşletmelerin toplum hayatında artan önemi, yönetim kavram ve uygulamaları üzerinde daha fazla yoğunlaşılmasını beraberinde getirmiştir. Çünkü bir yöneticinin başarısızlığı, pek çok kişi veya grubu etkilemektedir. İşletmede paydaşlara karşı sorumlulukların yerine getirilmemesi, yanlış ve yetersiz bir organizasyon yapısının kurulması, organizasyonlarda gerekli değişim ve dönüşümlerin gerçekleştirilmemesi, iletişim konusundaki yetersizlikler, kurumsallaşmanın yeterli düzeyde olmaması, kurumsal yönetimin işletmeyle bütünleştirilememesi, stratejik ve operasyonel açıdan karar vermede problemlerin yaşanması, yönetici-çalışan ya da çalışanların kendi aralarında yaşanan anlaşmazlıklar sonucunda ortaya çıkan çatışmalar, personel seçiminin hem nitelik hem de nicelik açısından işletmenin amaçlarına uygun gerçekleştirilememesi, insan kaynakları planlamasının etkin bir şekilde yapılamaması, karşılaşılan krizlerin etkin yönetilememesi veya krize neden olabilecek 
faktörler için proaktif bir bakış açısıyla önlemlerin yeterli düzeyde alınamaması örgütsel başarısızlığa neden olabilecek faktörlerdir. Bu faktörlerin her işletmede farklı ş̧ekillerde ve düzeylerde ortaya çıkacağı söylenebilir. Başarısızlığın bağlamı dışsal etkileri içerebilse bile, başarısızlığın kontrol odağı işletmenin içindedir.

Stratejik planlama, inovasyon, yeniden yapılanma ve organizasyon yapısının yeniden tasarlanması konusundaki uzun vadeli çabalar, kurumsal skandallar, kusurlu ürünler, zehirli sızıntılar, çalışan şiddeti, tesis patlamaları veya terör saldırıları ile yok olabilir. Dahası, bu tür felaketlerin etkileri bir işletmenin imajını etkileyebilir ve bu negatif etki onlarca yıl geçmek bilmeyebilir. Bazı durumlarda, meydana geldiği gibi Exxon Valdez petrol sızıntısı ve Union Carbide'ın Bhopal felaketinin ardından tüm endüstrinin etkilenmesi de bir sonuçtur (Seeger ve diğerleri, 2005, s. 78-79).

Yöneticiler tarafından yönetim ve organizasyon alanındaki örgütsel başarısızlığa neden olabilecek her bir konu ayrıntılı bir şekilde incelenmeli ve çözüm önerileri ya da önleyici önlemlerle ortadan kaldırılmalı ve engellenmelidir. Örgütsel başarısızlığa neden olabilecek faktörler; işletmelerin faaliyette bulundukları sektörün özelliklerine, büyüklüğüne, türüne (üretim ya da hizmet işletmesi), yaşına, organizasyon yapısına, benimsediği yönetim uygulama ve yaklaşımlarına göre farklılık gösterebilecektir. Literatür incelendiğinde örgütsel başarısızlığa neden olabilecek faktörlerin etkileri ayrı ayrı önemliyken, asıl göz önünde bulundurulması gereken durum kümülatif etkileridir. Sürekli değişen çevre koşulları ile karşı karşıya kalan işletmeler stratejik çalışmalara önem vermezler ise başarılı olma şansları yok denecek kadar azdır.

İşletmelerin uzun vadede yaşamlarını sürdürebilmeleri, müşteri istek ve beklentilerine uygun mal ve hizmetleri üretmelerine ve bunları tüketicilere ulaştırmalarına bağlıdır. Bu noktada, işletmelerde örgütsel başarısızlığa neden olabilecek üretim ve pazarlama fonksiyonları alanındaki her bir faktörün stratejik bir șekilde incelenmesi ve gerekli tedbirlerin alınması önem kazanmaktadır.

Örgütsel başarısızlık faktörlerinden işletmelerin finansal başarısızlığa sebep olan etkileri planlı bir biçimde analize tabi tutularak detaylı bir şekilde incelenmesi gereklidir. İşletmelerin finansal başarısızlıklarının sebebiyet verdiği dolaylı ve doğrudan maliyetleri mevcuttur. Bu maliyetler işletmenin içinde bulunduğu finansal sistemin fonları daha etkin bir biçimde kullanabilmesine engel teşkil etmektedir. Finansal başarısızlık yaşayan işletmelerin sayılarının azaltılabilmesi yalnızca iş dünyası açısından önemli olmamakla birlikte finansal başarısızlıkların azalmış olması ekonomik ve toplumsal problemleri de azaltmaya yardımcı olmaktadır. Finansal başarısızlıklarda artış olduğu zamanlarda istihdam problemi ortaya çıkar, üretim ve yatırım azalır buna bağlı olarak da gelirler azalmaktadır.

İşletme içi ve işletme dışı faktörlerin çok dikkatli bir şekilde izlenmesi finansal yönden başarısızlığın olumsuz yöndeki etkilerinden de koruma sağlamaktadır. İşletmelerin oluşan riskleri yönetebilme ve bunları firsata çevirebilme yeteneklerine haiz olmaları halinde finansal başarısızlığa uğramaksızın yaşamlarını sürdürebilmeleri ve de karlılıklarını devam ettirebilmeleri mümkündür

İşletmeler, örgütsel başarısızlık yaşamamaları için, diğer birimlerle iletişim içinde bulunarak, bilgiye dayanan iş yapma tekniklerini uygulamaları gerekmekte aynı zamanda da toplam kalite yönetim anlayışını tüm birimlerin benimseyerek uygulaması gerekmektedir. Bilgiye dayanmayan iş yapma teknikleri beraberinde finansal başarısızlıkları da getirmektedir. Finansal yönden oluşacak bu başarısızlıkları önleyebilmenin en etkili yolu problemlerle karşılaşmadan önce tedbirler almaktır. Muhtemel problemlerin belirlenmesi ve gereken tedbirlerin alınabilmesi etkili kısa ve uzun vadeli planlama yöntemlerinin işletme içinde uygulanması ile mümkün olabilmektedir. İşletmeler katlanabilecekleri riskleri ve etkilerini çok iyi hesaplamak zorundadırlar.

Yazar Katkı Oranları: 1. Yazar \%40, 2. Yazar \%35, 3. Yazar \%25 oranında katkı sağlamıştır. 


\section{Kaynakça}

Akdağ, M. (2001). Halkla İlişkiler ve Kriz Yönetimi (Yayımlanmamış Yüksek Lisans Tezi), Selçuk Üniversitesi Sosyal Bilimler Enstitüsü, Konya

Aktaş, R., Doğanay, M. ve Yıldız, B. (2003). Mali Başarısızlığın Öngörülmesi: İstatistiksel Yöntemler ve Yapay Sinir Ağı Karşılaștırması, Ankara Üniversitesi S.B.F. Dergisi, 58(4), 1-24.

Altman, E. I. ve Hotchkiss, E. (2006), Corporate Financial Distress and Bankruptcy: Predict and Avoid Bankruptcy, Analyze and Invest In Distressed Debt, 3rd Edition, New Jersey: John Wiley\&Sons.

Altunışık, R., Özdemir, Ş. ve Torlak, Ö. (2016). Pazarlama İlkeleri ve Yönetimi, Gözden Geçirilmiş 2. Baskı, İstanbul: Beta Yayınevi.

Atilla, İ. (2016). Aile Şirketlerinde Kurumsallaşma ve Kurumsal Yönetim Uygulamaları, İstanbul: Türkmen Kitabevi.

Aydın, S. (2020). Örgütsel Yabancılaşma, (Ed: M. Avı ve E. Kara), Örgütsel Davranışta Güncel Konular, 163-177, İstanbul: Hiper Yayın.

Baydaş, A., Bakan, İ. ve Özyılmaz, A. (2015). Kriz ve Kriz Yönetimi, (Ed: İ. Bakan), Çağdaş Yönetim Yaklaşımları: İlkeler, Kavramlar ve Yaklaşımlar, İstanbul: Beta Basım.

Bayın Donar, G. (2019). Örgütsel Sessizlik, (Ed: Y. Demir Uslu, Y. Hancıoğlu, G. Yeşilaydın, N. Oral Kara), Örgütsel Yaklaşımlar-I, 276-296, Eskişehir: Nisan Kitabevi.

Beheshtifar, M. ve Zare, E. (2013). Interpersonel Conflict: A Substantial Factor to Organizational Failure, International Journal of Academic Research in Business and Social Sciences, 3(5), 400-407.

Brigham; E. F. ve Gapenski L. C. (1994). Financial Management: Theory and Practice, 7.Edition, The Dryden Press.

Brown, A. D. ve Starkey, K. (2000). Organizational Identity and Learning: A Psychodynamic Perspective, Academy of Management Review, 25(1), 102-120.

Burnes, B. ve Jackson, P. (2011). Success and Failure in Organizational Change: An Exploration of the Role of Values, Journal of Change Management, 11(2), 133-162.

Can, H., Kavuncubaşı, Ş. ve Yıldırım, S. (2012). Kamu ve Özel Kesimde İnsan Kaynakları Yönetimi, 7.Baskl, Ankara: Siyasal Kitabevi.

Cezlan, E. Ç. (2020). Örgütsel İntikam, (Ed: Y. Demir Uslu, Y. Hancıoğlu, G. Yeşilaydın), Örgütsel Yaklaşımlar-II, 171-186, Eskişehir: Nisan Kitabevi.

Çivici, T., Kale, S. (2009). İnșaat Firmalarının Kurumsal Çevrelerine Stratejik Tepkileri, Balıkesir Üniversitesi Fen Bilimleri Enstitüsü Dergisi, 11 (2), 94-109.

Dağlı, H. (1994). İşletme Başarısızlıkları ve Alınması Gerekli Önlemler, Verimlilik Dergisi, Sayı: 1, Ankara: MPM Yayınları.

De Bono, E. (2000). Rekabet Üstü (Sur/Petition), (Çev: O. Özel), 2. Basım, İstanbul: Remzi Kitabevi.

Eren, E. (2008). Yönetim ve Organizasyon (Çağdaş ve Küresel Yaklaşımlar), 8.Baskı, İstanbul: Beta Basım Yayım.

Ertan, A. S., Ersan, Ö. (2018). Finansal Başarısızlı̆̆ı Belirleyen Etkenler: Türkiye İmalat Sektörü Örneği, Marmara Üniversitesi İktisadi ve İdari Bilimler Dergisi, 40(2), 181-207.

Ferrell, O. C., Hirt, G. A., Ferrell, L. (2017). İşletme, (Çeviri ed: U. Akküçük), Ankara: Nobel Akademik Yayıncılık. (Business (4th edition) orijinal çalışma basım tarihi 2013).

Gel, O. (2007). CRM Yolculuğu. İstanbul: Sistem Yayıncılık.

Genç, N. (2004). Yönetim Organizasyon-Çağdaş Sistemler ve Yaklaşımlar, Ankara: Seçkin Yayıncılık.

Gillespie, N., Dietz, G. (2009). Trust Repair after Organizational-Level Failure, Academy of Management Review, 34(1), 127-145.

Gökalp, Y., Demir Uslu, Y. (2020). Örgütsel Sahtekarlık, (Ed: Y. Demir Uslu, Y. Hancıoğlu, G. Yeşilaydın), Örgütsel Yaklaşımlar-II, 255-269, Eskişehir: Nisan Kitabevi.

Habersang, S., Küberling-Jost, J., Reihlen, M., Seckler, C. (2019). A Process Perspective on Organizational Failure: A Qualitative Meta-Analysis, Journal of Management Studies, 56(1), 19-56.

Hancıoğlu, Y., Türkoğlu, S. (2017). Değişen Rekabet Anlayışı ve Sürdürülebilirliğin İşletmeler Üzerindeki Etkileri BIST Sürdürülebilirlik Endeksi'ndeki İşletmelerin Etkinliğinin Araştırılması, Uluslararası İktisadi ve İdari İncelemeler Dergisi, 16. UİK özel sayısı, 237-252. 
İçerli, M. Y., Akkaya, G. C. (2006). Finansal Açıdan Başarılı Olan İşletmelerle Başarısız Olan İşletmeler Arasında Finansal Oranlar Yardımıyla Farklılıkların Tespiti, Atatürk Üniversitesi İktisadi ve İdari Bilimler Dergisi, 20(1), 413-421.

İlyasoğlu, E. (1983). Üretim Sistemlerinin Yönetimi, 2.Baskı, İstanbul: Venüs Ofset.

İslamoğlu, A. H. Altunışık, R. (2017). Tüketici Davranışları, İstanbul: Beta Basım Yayım Dağıtım A.Ş.

Karabulut, A. T. (2020). Kurumsal Yönetim ve Yönetim Kurulları, (Ed: P. Başar, D. Celayir), Kurumsal Yönetim ve Risk Yönetimi, 141-149, Ankara: Nobel Akademik Yayıncılık.

Koçel, T. (2015). İșletme Yöneticiliği,16. Baskı, İstanbul: Beta Basım A. Ș.

Kotler, P., Armstrong, G. (1997). Principles of Marketing, 7th Edition, New Jersey: Prentice Hall.

Köksal, K. (2007). Yükseköğretimde Örgüt Kültürü ve Alan Araştırması, Yayınlanmamış Yüksek Lisans Tezi, Balıkesir Üniversitesi Sosyal Bilimler Enstitüsü, Balıkesir.

Limon, S. (2020). Örgütsel Dedikodu, (Ed: Y. Demir Uslu, Y. Hancıoğlu, G. Yeşilaydın), Örgütsel Yaklaşımlar-II, 108-118, Eskişehir: Nisan Kitabevi.

Longenecker, C. O., Simonetti, J. L., Sharkey, T. W. (1999). Why Organizational Fail: the View from The Front-Line, Management Decision, 37(6), 503-513.

Marangoz, M. (2016). Girișimcilik, 3.Baskı, İstanbul: Beta Basım.

McMillan, C. J., Overall, J. S. (2017). Crossing The Chasm and over The Abyss: Perspectives on Organizational Failure, Academy of Management Perspectives, 31(4), 271-287.

Mellahi, K., Wilkinson, A. (2004). Organizational Failure: A Critique of Recent Research and A Proposed Integrative Framework, International Journal of Management Reviews, 5/6(1), 2141.

Mellahi, K., Wilkinson, A. (2010). Managing and Coping with Organizational Failure: Introduction to the Special Issue, Group \& Organization Management, 35(5), 531-541.

Meydan, C. H. (2010),Kaynak Bağımlılığı, İşlem Maliyetleri, Örgütsel Ağ Ve Yeni-Kurumsal Kuram ile Örgütlerin İttifak Oluşturma Sebepleri Üzerine Bir İnceleme, Savunma Bilimleri Dergisi, 9 (2), 17-40.

Miner, A. S., Kim, J. Y., Holzinger, I. W., Haunschild, P. (1996). Fruits of Failure: Organizational Failures and Population-Level Learning, (Ed: In J. B. Keys, L. N. Dosier.), 239-244, Academy of Management Best Paper Proceedings.

Nutt, P. C. (2002). Why Decisions Fail: Avoiding the Blunders and Traps that Lead to Debacles, San Francisco: Berrett-Koehler Publishers.

Okka,0.(2009). Finansal Yönetim Örnek Olayları ve Örnek Çözümler, 2. Baskı, İstanbul: Nobel Yayın Dağıtım.

Özalp, İ., Besler, S., Tonus, Z. (2006). Örgütsel Başarısızlık (Organizational Failure): Başarılı İşletmelerin Bakış Açısından Örgütsel Başarısızlık Nedenleri ve Çözüm Yolları, İktisat, İşletme ve Finans Dergisi, 21(249), 121-134.

Özkalp, E., Kırel, Ç. (2005). Örgütsel Davranış, Eskişehir: T.C. Anadolu Üniversitesi Eğitim, Sağlık ve Bilimsel Araştırma Çalışmaları Vakfi, Yayın No: 149.

Poyraz, E. (2008). Açıklamalı Örneklerle Finansal Yönetim, Bursa: Ekin Kitabevi.

Pfeffer, J., Gerald R. S. (1978), The External Control of Organizations: A Resource Dependence Perspective, New York: Harper and Row.

Sayılgan, G. (2017). Soru ve Yanıtlarıyla İşletme Finansmanı, 7.Baskı, Ankara: Siyasal Kitabevi.

Seeger, M. W., Ulmer, R. R., Novak, J. M., Sellnow, T. (2005). Post-crisis Discourse and Organizational Change, Failure and Renewal, Journal of Organizational Change Management, 18(1), 78-95.

Sheppard, J.P. (1995). A Resource Dependence Approach to Organizational Failure, Social Science Research, 24, 28-62.

Taşdöven, H. (2015). İç Güvenlik Teşkilatlarında Örgütsel Başarısızlığın Belirleyicileri, Bartın Üniversitesi İ.I..B.F. Dergisi, 6 (12), 421-439.

Taşpınar Cengiz, D., Turanlı, M., Bağdatlı Kalkan, S., Köse, İ. (2015). Türkiyedeki İşletmelerin Finansal Başarısızlığının Faktör Analizi ve Diskriminant Analizi ile İncelenmesi, İstanbul Üniversitesi İktisat Fakültesi Ekonometri ve İstatistik Dergisi, 23, 62-79.

Taştan, S. (2020). Kurumsal Yönetim Çerçevesinde Etik Sorumluluk ve Kurumsal Vatandaşlık, (Ed: P. Bașar, D. Celayir), Kurumsal Yönetim ve Risk Yönetimi, 117-139, Ankara: Nobel Akademik Yayıncılık. 
Tekin, E. (2020). Örgütsel Mağduriyet, (Ed: Y. Demir Uslu, Y. Hancıoğlu, G. Yeşilaydın), Örgütsel Yaklaşımlar-II, 210-227, Eskişehir: Nisan Kitabevi.

Tekin, M. (2012). Üretim Yönetimi, 8. Baskı,. Konya: Günay Yayınevi.

Thornhill, S., Amit, R. (2003). Learning from Failure: Organizational Mortality and The Resourcebased View, Analytical Studies Branch Research Paper Series, Canada: Micro-Economic Analysis Division.

Üreten, S. (2006). Üretim/İșlemler Yönetimi: Stratejik Kararlar ve Karar Modelleri, Gözden Geçirilmiş 5. Baski, Ankara: Gazi Kitabevi.

Varol, A. (2019). Tüm Boyutlarıyla Kurumsal Sosyal Sorumluluk, İstanbul: Cinius Yayınları.

Yeşilaydın, G. (2019). Örgütsel Sinizm, (Ed: Y. Demir Uslu, Y. Hancıoğlu, G. Yeşilaydın, N. Oral Kara), Örgütsel Yaklaşımlar-I, 297-311, Eskişehir: Nisan Kitabevi.

Yıldırım, E. (2012). Müșteri İlişsileri Yönetiminde Bilgi Yönetimi ve Teknoloji Desteği İle CRM Analizi (Yüksek Lisans Tezi), Haliç Üniversitesi, Sosyal Bilimler Enstitüsü, İstanbul.

\section{Extended Abstract}

Today's understanding of competition is changing with globalization, developments in information and communication technologies, and the increasing importance of innovation. Businesses are moving towards new pursuits with a changing understanding of competition. The objectives of the businesses also differ in order to adapt to the changing understanding of competition. Businesses need to make profit, serve the society and be sustainable.In order to achieve this, they operate at a high efficiency level with less labor, time and cost. Businesses that aim to achieve multiple goals efficiently and effectively at the same time are likely to face organizational failure due to both environmental and organizational factors. (aradaki cümleyi çıarttım) The only constant thing in businesses is change. Businesses that cannot keep up with the changes, do not have a flexible structure, and have insufficient organizational learning may face the concept of organizational failure. Situations such as a disruption in the departments (functions) of businesses, the adoption of the wrong strategy, the transfer of incorrect decisions to practice, and the static handling of events reveal the concept of organizational failure. There are many factors that cause organizational failure in businesses. In the model created by Melahi and Wilkinson (2004: 32-33), the factors of organizational failure are discussed under four headings: Environmental factors (technological uncertainties, regulatory changes, demographic changes, economic changes), ecological factors (density, size, age, industry life cycle), organizational factors (top management tenure, homogeneity in senior management, managerial achievements, past performances), psychological factors (managerial perceptions). However, in order to better understand organizational failure, it is necessary to understand how external factors and organizational factors interact to cause failure. These factors can vary in each of the businesses. It is the responsibility of senior managers and department managers to be able to identify, manage and eliminate organizational failure. Every manager should be aware of the risk of failure and should play an active role in eliminating failure. Situations that may cause organizational failure can sometimes be ignored by managers by considering them as insignificant, temporary, affecting a certain function or a certain stakeholder. Every factor that may cause organizational failure, regardless of the size of its impact on the business, should be examined in detail by the managers, and regulatory measures should be taken in order to eliminate or reduce it. Otherwise, the sustainability of the business will be compromised, the cumulative effect of organizational failure may possibly lead to the end of the life of the business. Identifying and preventing factors that can lead businesses to organizational failure is the function of an effective management. The ability to foresee some factors in advance and take the necessary measures allows businesses to change on a planned basis. As a result of the conducted studies, it is seen that organizational failure in businesses occurs if businesses cannot be sufficient to identify, prevent or respond appropriately to changes that occur in their problem areas.

In this regard, the concept of organizational failure and the factors that can cause organizational failure are discussed separately in terms of business functions. The reason for making an evaluation in terms of all business functions is that each function contributes to the achievement of the goals of the business. Organizational failure can only be fully understood from a holistic point of view. The study also discusses how failure factors can be transformed into success factors by conducting a holistic assessment, and what responsibilities the busines's function managers should take. As a result of the theoretical assessment, it can be said that some failure factors arising from business functions are related to each other and negatively affect the effectiveness of the enterprise. It will be possible to reduce or eliminate this negative effect with an interdisciplinary holistic perspective. 